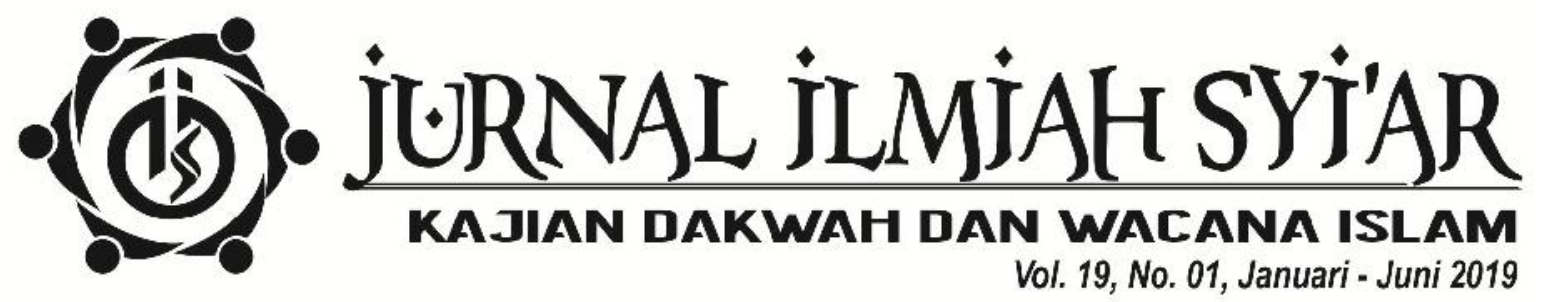




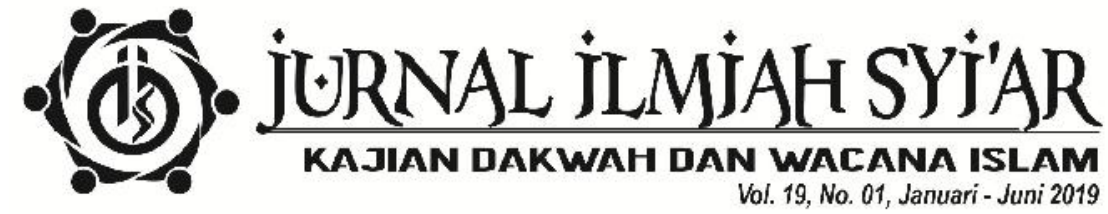

MITRA BESTARI

Khomsyahrial Romli (UIN Raden Intan Lampung)

Nelly Marhayati (IAIN Bengkulu)

Andi Dermawan (UIN Sunan Kalijaga Yogyakarta)

Bayu Mitra Aditya Kusuma (UIN Sunan Kalijaga Yogyakarta)

\section{PENANGGUNG JAWAB}

Suryani

REDAKTUR

Pebri Prandika Putra

EDITOR

Ihsan Rahmat

SEKRETARIS

Haqqi Annazili

DESAIN GRAFIS

Hymawandra

\author{
ALAMAT REDAKSI \\ Fakultas Ushuluddin, Adab, dan Dakwah \\ Institut Agama Islam Negeri Bengkulu \\ Jl. Jalan Raden Patah, Kelurahan, Pagar Dewa, Selebar, Pagar Dewa, Selebar, Kota \\ Bengkulu, Bengkulu 65144, Telp. \\ http:// ejournal.iainbengkulu.ac.id/index.php/syiar
}




\section{PENGANTAR REDAKSI}

Alhamdulillah, Jurnal Ilmiah Syi'ar, Vol. 19, No. 1 telah terbit tepat pada waktunya. Redaksi bersyukur ke hadirat Allah SWT atas seluruh karunia yang telah diberikan, baik yang terlihat ataupun kasat mata. Kemudian, shalawat beserta salam semoga tercurah bagi Nabi Muhammad SAW. Seorang rasul yang mempraktikkan berbagai metode dakwah bagi umat seluruh alam. Pada edisi ini, Jurnal Ilmiah Syi'ar (JIS) mengalami banyak pembenahan dalam rangka menuju akreditasi. Perubahan pertama datang dari ukuran jurnal cetak yang dianggap terlalu besar, sehingga redaksi memutuskan untuk menyesuaikan seukuran buku standar ISBN. Menetapkan waktu terbit dua kali dalam satu tahun, yakni edisi Januari - Juni diterbitkan pada Juni dan Juli - Desember diterbitkan pada Desember. Satu edisi berisi delapan jurnal berkualitas yang dikelola dengan sistem Open Journal System (OJS).

Pada edisi ini juga, redaksi bekerja sama dengan mitra bestari yang dinilai pakar pada salah satu fokus JIS, yaitu Komunikasi dan Penyiaran Islam, Manajemen Dakwah, Pengembangan Masyarakat Islam, Bimbingan Konseling Islam, dan Kesejahteraan Sosial. Selanjutnya, menyediakan logo khusus untuk JIS dengan tujuan mudah dikenali dan profesionalisme. Logo didesain dengan karakter tulisan 'JIS' berbentuk bulat bermakna bahwa Syi'ar Islam diperuntukkan bagi umat seluruh alam. Dakwah tidak membedakan suku, ras, agama, bangsa, dan negara. Kemudian, di luar karakter ada simbol orang yang saling bergandengan bermakna pola baru Syi'ar Islam di masa depan dengan model kolaboratif. Redaksi berpandangan bahwa kompleksitas kehidupan umat tidak mampu lagi diselesaikan dengan cara parsial atau metode dakwah perorangan.

Metode syi'ar Islam tidak mungkin dipisahkan dari sunnah Rasulullah SAW dan Khulafaur Rasyidin. Tulisan pertama mengangkat pembahasan tentang 'Manajemen Baitul Mal pada Masa Khalifah Umar Bin Khathab R.A: Sebuah Tinjauan Sejarah.' Fitmawati sebagai penulis tunggal telah banyak menulusuri proses terbentuknya baitul mal di madinah, sumber dana yang bisa menjadi pemasukan, tata cara pembagian, hingga hal teknis lainnya. Kajian ini ternyata juga mampu menjelaskan sistem ekonomi syariah di masa khalifah kedua. Tulisan kedua berupa pemikiran tentang konseling Islam berjudul 'Konselor dalam Penguatan Nilai dan Moral: Strategi Membentuk Generasi Religius' oleh Muahammad Nikman Nasir. Nasir mempertahankan argumen bahwa di era milenial, konselor membutuhkan nash-nash agama untuk membangun moral klien atau peserta didik. Agama menjadi titik tolak sebagai sumber kekuatan, agama sebagai budaya, dan agama sebagai konteks.

Ashadi Cahyadi mengisi slot ketiga dengan pembahasan 'Pembangunan dan Pemberdayaan Manusia melalui Dana Desa: Pola dari Masa Lalu hingga Sinergitas yang Rancu.' Asumsi studi ini adalah sinergitas infrastruktur diikuti dengan pemberdayaan masyarakat akan menghasilkan 
kesejahteraan yang berkelanjutan. Tetapi temuan mengatakan rasionalitas ini dinilai tidak berjalan bersamaan karena memberikan porsi yang besar untuk infrastruktur dan mengecilkan pemberdayaan manusia. Tulisan keempat milik Sifatul Aliyah dan Bayu Mitra A. Kusuma 'Tuntutan Kinerja dalam Keterancaman Kerja: Dilema Karir Penyuluh Agama Non-Pegawai Negeri Sipil.' Penulis banyak mengeksplor tentang keresahan penyuluh agama, langkah propaganda, hingga kebijaksanaan yang telah dikeluarkan pemerintah. Tulisan kelima berjudul 'Falsafah Huma Betang di Kalimantan Tengah: Sebuah Pergulatan Identitas Konselor Dayak Muslim' oleh Dody Riswanto. Dody menemukan konselor dayak muslim terbentur oleh persepsi negatif dari lingkungan sosial. Kemungkinan latar agama menjadi arus utama yang perlu dipertimbangkan untuk lingkungan Dayak yang rerata menganut agama berbeda. Penyelesaian Falsafah Huma Betang yang mengandung nilai-nilai toleransi dan saling menghargai antar pemeluk agama dinilai sebagai jembatan yang mampu mereduksi persepsi negatif.

Tulisan keenam berjudul 'Sumber Daya Manusia Koperasi Jasa Keuangan Syariah (KJKS) di Kota Padang: Dilema antara Pengelolaan dan Pemahaman Konsep.' M. Zaky Mubarak Lubis dan Netta Agusti menemukan bahwa 39\% pengelola KJKS belum memahami konsep dasar ekonomi Islam. Robeet Thadi menjadi penulis ketujuh dengan pembahasan 'Literasi Media Khalayak di Era Keberlimpahan Infomasi di Media Massa.' Ada pergeseran di era keberlimpahan informasi, yakni dari sulitnya mencari informasi menjadi sulitnya menyaring informasi. Thadi menekankan pentingnya kemampuan literasi media individu untuk melihat dan membedakan dunia nyata dan dunia yang diproduksi oleh media. Tulisan terakhir oleh Sugeng Sejati dengan judul 'Implikasi Egosentris dan Spiritual Remaja dalam Mencapai Perkembangan Identitas Diri.' Temuan utamanya adalah pengembangan identitas remaja yang egosentris dan spiritual ternyata menjadikan remaja tersebut memiliki prinsip dengan peran penting dalam kehidupan dan nilai dalam masyarakat.

Demikian catatan beberapa perubahan jurnal dan cuplikan dari isi JIS Vol. 19, No. 1. Redaksi menyadari bahwa masih terdapat berbagai kekurangan. Sehingga kritikan dan saran yang bersifat membangun sangat diharapkan demi penyempurnaan jurnal ini kedepannya. Akhirnya redaksi mengucapkan banyak terimakasih kepada berbagai pihak yang turut mendukung lahirnya edisi ini. Mulai dari para penulis yang setia merevisi berbagai kekurangan tulisan, para mitra bestari, tim redaksi yang bekerja maksimal, dan lainnya. Redaksi menunggu karya-karya terbaik penulis pada edisi berikutnya. Selamat membaca!!!

Pagar Dewa, Juni 2019 a.n TIM REDAKSI JIS Ihsan Rahmat 


\section{DAFTAR ISI}

$\begin{array}{ll}\text { Pengantar Redaksi } & \text { iii }\end{array}$

Daftar Isi

MANAJEMEN BAITUL MAL PADA MASA KHALIFAH UMAR BIN 1-29

KHATHAB R.A: SEBUAH TINJAUAN SEJARAH

Fitmawati

KONSELOR DALAM PENGUATAN NILAI DAN MORAL:

$30-42$

STRATEGI MEMBENTUK GENERASI RELIGIUS

Muahammad Nikman Nasir

PEMBANGUNAN DAN PEMBERDAYAAN MANUSIA MELALUI DANA

DESA: POLA DARI MASA LALU HINGGA SINERGITAS YANG RANCU Ashadi Cahyadi

TUNTUTAN KINERJA DALAM KETERANCAMAN KERJA: DILEMA

$55-67$

KARIR PENYULUH AGAMA NON PEGAWAI NEGERI SIPIL

Sifatul Aliyah, Bayu Mitra A. Kusuma

FALSAFAH HUMA BETANG DI KALIMANTAN TENGAH: SEBUAH

$68-76$

PERGULATAN IDENTITAS KONSELOR DAYAK MUSLIM

Dody Riswanto

SUMBER DAYA MANUSIA KOPERASI JASA KEUANGAN SYARIAH

$77-89$

(KJKS) DI KOTA PADANG: DILEMA ANTARA PENGELOLAAN

DAN PEMAHAMAN KONSEP

M. Zaky Mubarak Lubis, Netta Agusti

LITERASI MEDIA KHALAYAK DI ERA KEBERLIMPAHAN INFOMASI DI

90-102

MEDIA MASSA

Robeet Thadi

IMPLIKASI EGOSENTRIS DAN SPIRITUAL REMAJA

103-126

DALAM MENCAPAI PERKEMBANGAN IDENTITAS DIRI

Sugeng Sejati 


\title{
MANAJEMEN BAITUL MAL PADA MASA KHALIFAH UMAR BIN KHATHAB R.A: SEBUAH TINJAUAN SEJARAH
}

\author{
Fitmawati \\ Fakultas Syariah dan Ekonomi Islam \\ Institut Agama Islam Negeri Curup
}

Korespondensi dengan penulis:

Fitmawati, Telp: 081537548425

Email: fitmawati@iaincurup.ac.id

Keywords:

Management, Baitul

Mal, Umar Bin

Khathab.
Kata kunci:

Manajemen, Baituk

Mal, Umar bin

Khathab
Abstract

Umar bin Khathab was the chaliph of about 10 years. He was well know as his ekspansion policies. He introduced a goverment administrasion system by dividing its area and building Baitul mal to be an independent institution. Those exspansion policies had reached the goal successfully, so as the income of the a sure of the Baitul mal were overabundance. Then, the chaliph Umar managed it through accumulation and emission by forming Diwan. He had applied the concept of Islamic management long before the weit management exisheted. The concent of Umar's give preference on manner which related to the value of faith and truth. He also applied the Syura concept on manner and management activity, especially those which related to the determination of decision. Dividing goverment area and Amir and Madinah as the center of polity and Baitu mal the independent institution out of the goverment intervension became chaliph Umar contribution Islamic polity.

\begin{abstract}
Abstrak
Umar bin Khathab menjadi khalifah sekitar 10 tahun. Dia sangat dikenal sebagai kebijakan ekspansinya. Dia memperkenalkan sistem administrasi pemerintahan dengan membagi wilayahnya dan membangun Baitul mal menjadi lembaga independen. Kebijakankebijakan perluasan itu telah mencapai tujuan dengan sukses, sehingga pendapatan orang-orang Baitul mal itu terlalu banyak. Kemudian, khalifah Umar mengaturnya melalui akumulasi dan emisi dengan membentuk Diwan. Dia telah menerapkan konsep manajemen Islam jauh sebelum manajemen weit exisheted. Konsentrasi Umar memberikan preferensi pada cara yang terkait dengan nilai iman dan kebenaran. Dia juga menerapkan konsep Syura pada cara dan aktivitas manajemen, terutama yang terkait dengan penentuan keputusan. Membagi daerah pemerintahan dan Amir dan Madinah sebagai pusat pemerintahan dan Baitu mal sebagai lembaga independen yang keluar dari campur tangan pemerintah menjadi kontribusi Umar.
\end{abstract}




\section{PENDAHULUAN}

Pada masa Rasulullah SAW maupun Abu Bakar RA pengumpulan dan pendistribusian zakat serta pungutan-pungutan lainnya dilakukan secara serentak, yang artinya pendistribusian dana tersebut langsung dilakukan setelah pengumpulan. Sehingga para petugas Baitul mal setelah selesai melaksanakan tugasnya tidak lagi membawa sisa dana untuk disimpan. Namun setelah pemerintahan digantikan oleh Umar bin Khathab, pendistribusian tidak lagi dilakukan secara serentak. Harta Baitul mal dikeluarkan secara bertahap sesuai dengan kebutuhan yang ada, bahkan diantaranya disediakan dana cadangan. ${ }^{1}$

Adanya kebijakan mengenai dana cadangan yang disimpan untuk keperluan darurat mengindikasikan adanya praktik manajemen dari seorang khalifah (pemimpin) tentang perencanaan pengelolaan dana yang ada pada Baitul mal, mengingat ekspansi pada masa khalifah Umar semakin meluas dan semakin banyak harta yang mengalir ke Baitul mal kota Madinah sebagai kas negara. Sudah menjadi suatu keharusan seorang pemimpin mempunyai manajemen yang baik dalam kepemimpinan dengan segala kebijakannya. Sudah menjadi tanggung jawab bahwa khalifah mempunyai kewajiban untuk mensejahterakan rakyatnya. Menurut Taqyuddin An-Nabhani Baitul mal juga menjadi supplier bagi seluruh rakyat dan sarana pemelihara keseimbangan ekonomi (economi equilibrium). ${ }^{2}$

Studi ini mengkaji lebih dalam dan kritis bagaimana manajemen yang dijalankan oleh khalifah Umar bin Khatab terhadap pengelolaan hart Baitul mal sebagai kas negara, mengingat begitu banyaknya harta yang masuk ke dalam Baitul mal kota Madinah karena adanya politik ekspansi. Pengkajian ini ditujukan agar struktur pengilmuan mengenail ekonomi islam (Keungan Islam) yang berkaitan dengan Baitul mal terpapar jelas dan tegas sesuai dengan fakta sejarah pada masa itu. Hal ini sangat penting dikaji untuk melihat sejauh mana khalifah Umar bin Khatab memberikan konribusi dan perhatian serius dalam pengelolaan harta Baitul mal sebagai kas negara untuk kemakmuran rakyaknya.

\section{METODE}

Artikel ini menggunakan pendekatan sejarah untuk mengeksplorasi secara kritis dan melihat lebih jelas fakta-fakta yang terjadi pada masa pemerintahan Umar bin Khathab yang

${ }^{1}$ Mohammad Hidayat, The Sharia Economic Pengantar Ekonomi Syariah, (Jakarta: Zikrul Hakim, 2010). hlm. 186.

2 Taqyudin an-Nabhani, Membangun Sistem Ekonomi Alternatif Prespektif Islam. Judul asli AnNidhan al-Iqtisadi fil Islam, penerjemah Moh. Maghfur Wachid cet ke 5, (Surabaya: Risalah Gusti, 2000). hlm. 264-275. 
berkeanaan dengan Baitul mal memalui referensi atau buku-buku yang berkaitan dengan sejarah kepemimipinan khalifah Umar bin Khathab. Penelitian ini bercorak kepustakaan dengan menggunakan content analysis untuk mendapatkan dan menganalisis data primer maupun sekunder dengan memperhatikan isi teks. ${ }^{3}$ Setelah proses dilalui, barulah penulis akan menuliskannya menggunakan metode deskriptif yaitu dengan mendiskripsikan, menggambarkan, menuliskan secara sistematis faktual dan akurat mengenai fakta-fakta sejarah yang didapat, sifat-sifat serta hubungan antar fenomena yang diselidiki ${ }^{4}$ berkenaan bagaiman manajemen khalifah Umar dalam pengelolan dan penditribusian Baitul mal.

\section{HASIL DAN PEMBAHASAN}

\section{Manajemen}

Manajemen adalah ilmu dan seni dari suatu proses usaha perencanaan, pengorganisasian, pengarahan, pengkoordinasian, dan pengendalian kegiatan penggunaan sumber daya manusia serta benda dalam suatu organisasi secara efektif dan efesien. ${ }^{5}$ Menurut M. Fuad manajemen merupakan suatu proses yang melibatkan kegiatan perencanan, pengorganisasian, pengarahan, dan pengendalian yang dilakukan untuk mencapai sasaran perusahaan melalui pemanfaatan sumber daya yang ada. ${ }^{6}$ Dengan demikian manajemen memliki fungsi perencanaan, pengorganisasian, penggerakan/pelaksanaaan, dan pengawasan.

Terry dikutip oleh Tanthowi memberi pengertian bahwa manajemen adalah suatu proses tertentu dari planning, organizing, actuating, dan controlling. ${ }^{7}$ Defenisi manajemen dalam Islam tidak jauh dari pemahaman ini, manajemen dianggap sebagai ilmu sekaligus teknik (seni) kepemimpinan di awal Islam. Pemikiran manajemen dalam Islam bersumber dari nashnash al-Qur'an dan petunjuk Sunnah. Selain itu berasalkan nilai-nilai kemanusiaan yang berkembang dalam masyarakat pada waktu tersebut. Hal ini tidak berarti bahwa manajemen tidak dan belum dikenal sebelumnya. Kelahiran dan perkembangan manajemen bisa dikembalikan pada awal proses penciptaan alam ini. Hal ini dapat terlihat pada peradapan mesir klasik, terdapat bukti sejarah berupa piramida dan spinx yang mencerminkan adanya praktik manajemen, skill dan kompetensi.

\footnotetext{
${ }^{3}$ Bambang Prasetyo dan Lina Miftahul Jannah, Metode Penelitian Kualitatif, (Jakarta: Raja Grafindo Persada, 2005). hlm. 67.

${ }^{4}$ Moh. Nazir, Metode Penelitian, cet ke 3 (Jakarta: Ghalia Indonesia, 1988). hlm. 32-34.

${ }^{5}$ Sugianto Wiryaputra, Dasar-Dasar Manajemen,(Jakarta: BPK Gunung Mulia, 2008). hlm. 2.

${ }^{6}$ M Fuad, Christin H dkk, Manajemen Bisnis, (Jakarta: PT Gramedia, 2006). hlm. 92-93.

7 Jawahir Tanthowi, Unsur-Unsur Manajemen Menurut Ajaran al-Qur'an (Jakarta: Pustaka alHusna, 1983). hlm. 10.
} 


\section{Kepemimpinan Umar bin Khathab}

Umar dilahirkan di kota Makkah dengan nama lengkap Umar bin Khatab bin Nufail bin Abdul Uzza bin Riba'ah bin Abdullah bin Kart bin Raazaah bin Adi bin Ka'ab bin Lu'ai, Abu Hafsah Al-'Adawi. ${ }^{8}$ Ibunya bernama Hatamah binti Hisyam bin Al-Mughiroh, saudari Abu Jahl bin Hisyam. ${ }^{9}$ Hatamah adalah saudara sepupu Abu Jahal. Ayahnya bernama Khatab bin Nufail al- Mahzumi al-Quraisy dari Bani Adi.10 Suku Adi terpandang mulia mempunyai martabat tinggi dikalangan orang-orang Arab. Lingkungan keluarganya sangat menonjol dalam bidang ilmu pengetahuan. ${ }^{11}$ Umar juga mempunyai pengetahuan yang menonjol mengenai silsilah (genealogi) orang Arab yang dipelajari dari ayahnya. ${ }^{12}$

Pada masa kecilnya Umar ikut membantu ayahnya memelihara hewan ternak dan ikut berdagang. Dalam perjalanan berdagang Umar mendapat pengetahuan dari negeri-negeri yang dikunjunginya. ${ }^{13}$ Setelah masuk Islam Umar menjadi sosok yang pemberani dan kuat tak gentar bertarung dan tak pernah takut pada siapapun untuk membela Nabi dan kaum muslimin. Abdullah bin Mas'ud dalam Muhammad Husaen Haekal berkata:"Islamnya Umar suatu pembebasan, hijrahnya suatu kemenangan dan kepemimpinannya suatu rahmat". ${ }^{14}$ Masuknya Umar bin Khatab ke dalam Islam merupakan keuatan yang sangat besar dan berharga bagi dakwah Islam. Semenjak Umar masuk Islam Nabi Muhammad memberikan julukan dangan sebutan al-faruq. Umar adalah sahabat Nabi yang nasabnya bertemu dengan Nabi pada Ka'ab

8 Ismail bin Umar bin Katsir Asy-Syafi'i (al-Hafiz Ibnu Katsir), Serial Al-khulafa' Ar-Rasyidun 2 Umar bin Khaththab, Judul asli Al-Khulafa' Ar-Raasyidun penerjemah Umar Mujtahid, (Jakarta: Perisai Qur'an, 2012). hlm. 17. Untuk lebih jelas lihat Mustofa Abdul Qodir Atho' dalam kitab Mustadarok ala Shohihain, juz 3 bab Ma'rifah Shohabah, (Beirut: Dar al-Kutub al-Ilmiyah) hlm. 57.

${ }_{9}^{9}$ Menurut para ahli di bidang nasab dan kitab-kitab biografi, Ibu Umar bin Khatab adalah Hantamah binti Hasyim bin Al Mughiroh saudara Hisyam bin Al-Mughiroh. Dengan demikian Abu Jahl adalah saudara sepupu dari Umar.

${ }^{10}$ Hamdani Anwar, Masa al-Khulafa ar-Rasyidun, dalam M.Din Syamsudin, at. all, ed., Esiklopedi Tematis Dunia Islam, Vol II (Jakarta: PT Ichtiar Baru Van Hoeve, 2002). hlm. 38.

11 Taufiqurohman, Sejarah Sosial Politik Masyarakat Islam, (Surabaya: Pustaka Islamika Press, 2003) h.67 Umar juga memiiliki kecerdasan yang luar biasa dalam hal ini ia mampu memperkirakan segala hal-hal yang akan terjadi dimasa yang akan datang. Kelebihan-kelebihan yang dimilikinya itu menjadikan wakil kabilahnya, ketika terjadi perundingan-perundingan dengan suku-suku lain.

12 Muhammad Husain Haekal, Umar bin Khatab, diterjemahkan oleh Ali Audah judul asli AlFaruq Umar, (Bogor: Lintera Antar Nusa, 2013). hlm. 12.

${ }^{13}$ Sami bin Abdullah al-Maghlout, Jejak Khulafa Rasyidin 2 Umar bin Khatab, judul asli Atlas alKhaliafh Umar bin al-Khatab, diterjemah oleh Muflih Kamil, (Jakarta: Almahira, 2014). hlm. 12.

${ }^{14}$ Muhammaad Husaen Haekal, Umar bin Khatab... hlm. 32. 
bin Lu'ai bin Ghalib. Umar juga menjadi penasehat Nabi Muhammad SAW sepanjang umur Nabi Muhammad SAW. ${ }^{15}$

Umar mendampingi Nabi dengan penuh kesetiaan dan tanggung jawab untuk membawa Islam menuju kejayaan sampai wafatnya Nabi. Ketika Nabi wafat Umar mendampingi Abu Bakar menjalankan pemerintahan Islam. Bahkan Abu Bakar menjadikan Umar sebagai tangan kanannnya, nasehat-nasehat Umar selalu diminta Abu Bakar dalam menjalankan kepemimpinannya menjadi khalifah. Kekaguman dan kepercayaan Abu Bakar kepada Umar sangatlah besar. Sehingga waktu Abu Bakar sakit menjelang wafat, ia sudah memikirkan penggantinya sebagai khalifah agar umat Islam tidak mengalami perpecahan hanya karena permasalahan kepemimpinan. Secara diam-diam Abu Bakar meneliti masingmasing pemuka Islam pada waktu itu, pilihannya jatuh kepada Umar bin Khatab.

Untuk meyakinkan pilihannya tersebut, Abu Bakar berkonsultasi dengan tokoh-tokoh Islam mengenai penunjukan Umar sebagai pengganti, seperti Abdurrahman bin Auf, Usman bin Affan, Usaid bin Hudair Al-Anshari, Said bin Zaid dan Thalhah bin Ubaidah. ${ }^{16}$ Kemudian khalifah Abu Bakar memanggil Usman bin Affan untuk mencatat wasiatnya mengenai penentapan Umar bin Khatab sebagai pemimpin umat Islam dan kepala pemerintahan setelah ia wafat. Umar di bai'at di Masjid Nabawi dan mendapat gelar "Khalifah Khalifati Rasulillah" (pengganti-pengganti Rasul) dan khalifah pertama dengan gelar amirul mukminin. Umar bin Khatab di bai'at pada bulan Jumada al-akhirah tahun $13 \mathrm{H}$. Umar wafat pada tahun $23 \mathrm{H}$ setelah memangku jabatan selama 10 tahun lebih. Setelah menjadi khalifah Umar menajdi sosok pemimpin yang adil dan bijak, mempunyai keutamaan ilmu (ilmu fiqih) dan Allah memuliakan Islam melalui Umar sehingga.

Pada awal pemerintahannya, khalifah Umar harus menghadapi tantangan dan kesulitan, khususnya perang berkepanjangan di Syam. Kemudian Umar memulai misi penaklukan (ekspansi) dengan mengirim pasukan ke Irak di bawah pimpinan Abu Ubaidah bin Mas'ud Ats-Tsaqifi. Misi penaklukan ini adalah misi perluasan agama Allah yang dipenuhi cahaya iman dan bukan karena tamak akan kekuasaan. Keberhasilan ekspansi dan kebijakan khalifah Umar merupakan gambaran bagaiman khalifah Umar bukan hanya terkenal sebagai negarawan yang mampu menciptakan peraturan baru beliau juga mampu memperbaiki dan mengkaji ulang segala kebijaksanaan yang telah ada pada masa Nabi dan Abu Bakar.

15 Menurut para ahli sejarah sepakat bahwa Umar mengikuti semua peperangan bersama Rasulullah.Peperangan yang telah diikuti bersama Rasulullah yaitu dalam Badar, Uhud, Musthaliq, Ahzab, Hudaibiyah, Khaibar, Fathu Makkah, Hunain, dan perang Tabuk.

${ }^{16}$ Hamdani Anwar, Masa al-Khulafa ar-Rasyidun... hlm. 39. 
Sudah menjadi kewajiban seorang politikus untuk mempertimbangkan semua peristiwa disekitarnya dan dapat mengatur segala persoalan dengan pandangan yang lebih tajam. Jadi, pemerintahan Madinah pada masa pemerintahan khalifah Umar bisa dikatakan sebagai pemerintahan yang penuh dengan nilai dan prinsip demokrasi. Khalifah Umar ingin membangun negara Islam berdasarkan fondasi yang kuat yaitu keimanan kepada Allah, penegakan keadilan, serta diperkuat oleh kasih kasang yang tulus dan budi pekerti yang tinggi. Dengan demikian misi ekspansinya tidak karena haus akan kekuasaan namun karena ingin menyebarluaskan Islam (dakwah) yang penuh dengan kedamaian.

Khalifah Umar juga membagi wilayah administratif pada masa pemerintahan menjadi delapan provinsi Makkah, Madinah, Syiria, Jazirah, Bashra, Kuffah, Palestina dan Mesir Madinah sebagai ibu kota negara Islam. Masing- masing provinsi dipimpim oleh amir (gubernur). Dengan demikian dapat dikatakan bahwa khalifah Umar menggunakan sistem disentralisasi. Umar juga menempatkan hakim (qadhi) terkemuka di setiap daerah atau wilayah dan menetapkan mendaftar atau mencatat seluruh kekayaan para pejabat yang akan dilantik untuk ditempatkan di wilayah-wilayah pemerintahannya. Hal ini sebagai antisipasi adanya manipulasi, penggelapan kekayaan negara dan menghindari adanya penyalahgunaan wewenang dan korupsi. Umar menjadikan musyawarah menjadi dasar hukum dengan adanya dewan Syura'.17 Bukan itu saja khalifah Umar juga memisahkan antara lembaga eksekutif dan legislatif. Umar juga melakukan Pengadaan dan pembangunan masjid di setiap daerah taklukan, dikarenakan khalifah Umar menginginkan dakwah Islam disetiap daerah taklukan dapat terealisasi dengan adanya masjid-masjid yang telah dibangun di kota tersebut. Hal ini juga merupakan bentuk perhatian Umar terhadap pemeliharaan tauhid umat muslim.

Sedangkan dalam bidang ekonomi Umar melembagakan Biatul mal secara permanen, yang artinya Baitul mal ini bersifat independen. Pendirian Baitul mal ini dilengkapi dengan sistem administrasi yang tertata baik dengan membentuk diwan. Dalam pengelolaan Baitul mal khalifah Umar dan amilnya sebagai pemegang amanah. Pengelolaan Baitul mal ditingkat cabang dilakukan oleh pejabat setempat dan tidak bertanggung jawab pada gubernur. Pejabat-pejabat Baitul mal di cabang/provinsi mempunyai otoritas penuh dan bertanggung jawab pada pemerintahan pusat (khalifah).

Umar juga mencetuskan pembuatan kalender atau tahun hijiriyah yang di mulai dari hijrah Rasul ${ }^{18}$, menempa mata uang, membentuk tentara, mengatur gaji, mengangkat hakim-

17 Majelis syura ini pada zaman Nabi dan Abu Bakar beranggotakan 14 orang, yaitu 7 dari kaum muhajirin dan 7 dari kaum Anshar. Pada masa Umar Mejelis Suyura dijadikan sebagai media permusyawaratan untuk menyelesaikan segala persolan hukum dan manajemn pemerintahan.

${ }^{18}$ Taufiqurrahman, Sejarah Sosial Politik Masyarakat Islam... hlm. 72. 
hakim, dan mengadakan hisbah (pengawasan pasar, pengontrolan timbangan dan takaran, penjagaan terhadap tata tertib dan susila, dan pengawasan terhadap kebersihan jalan) ${ }^{19}$, jawatan pajak, kepolisian dan lainnya. Umar bin Khatab dicatat dalam sejarah sebagai orang pertama kali yang mendirikan kamp-kamp militer yang permanen. Khalifah Umar juga orang yang pertama kali memerintahkan panglima perang untuk menyerahkan laporan secara terperinci mengenai keadaan prajurit. Beliau juga membuat buku dan mencatat para prajurit dan mengatur secara tertib gaji, mengikut sertakan dokter, penerjemah dan penasehat yang khusus menyertai pasukan. ${ }^{20}$

\section{Baitul Mal Era Umar bin Khathab}

Setelah Umar bin Khatab menjadi khalifah, beliau mengumpulkan para bendaharawan serta memasuki rumah Abu Bakar dan membuka Baitul mal dan beliau hanya mendapatkan 1 dinar saja. Pada tahun $16 \mathrm{H}$ Abu Hurairah mengunjungi madinah dan membawa 500.000 dirham kharaj.21 Sehingga khalifah mengadakan pertemuan dengan majelis Syura' untuk menanyai pendapat mereka dan kemudian diputuskan bersama bahwa jumlah tersebut tidak untuk didistribusikan tapi untuk disimpan sebagai cadangan darurat. Sehingga dibutuhkan tempat untuk menyimpan dana sehingga Baitul mal dikembangkan fungsinya dan tidak hanya di ibu kota negara tapi seiring luasnya wilayah kekuasaan pemerintahan Islam, Baitul mal dibangun di cabang-cabang daerah/ kota provinsi. Maka Abdullah bin Arqam² di tunjuk sebagai pengurus Bait al-mal di Madinah, Abdullah ibn Ubaidah Al-Qaris dan Muayqab sebagai wakilnya. Khalifah Umar juga membentuk diwan, yaitu suatu tempat dimana para penulis administrasi Baitul mal berada, dan digunakan untuk keperluan penyimpanan arsiparsip.

Dalam Sami bin Abdullah al-Maghlout disebutkan bahwa diwan adalah lembaga atau tempat untuk menjaga semua yang berkenaan dengan lembaga kenegaraan berupa pekerjaan,

\footnotetext{
${ }^{19}$ A. Syalabi, Sejarah dan Kebudayaan Islam, Jilid 1 (Jakarta: PT Al-Husna Zikra, 1997). hlm. 263.

20 Amru Khalid, Jejak Para Khalifah, terjemahan Farur Mu'is judul asli "Khulafaur Rasul", (Solo:Aqwam, 2007). hlm. 117-118.

${ }^{21}$ Disebutkan bahwa Abu Hurairah sekembalinya dari Bahrain ditanya oleh Umar mengenai orang di sana, tanyanya, "Apa yang anda bawa? Jawab Abu Hurairah; "saya membawa 500.000 dirham". Umar terkejut, lalu tanyanya lagi, "sadarkah apa yang anda katakana?" Abu Hurairah mengulang lagi bahwa dia membawa 500.000 dirham. Umar mengira bicara Abu Hurairah sudah berlebihan sehingga mengulangi lagi pertanyaan itu. Setelah mendengar jawabannya yang pertama. Ia berkata "rupanya anda masih mengantuk. Pulanglah dulu dan tidurlah. Besok anda datang lagi." Keesokan harinya Abu Hurairah datang lagi dan menegaskan lagi bahwa ia membawa 500.000 dirham. Umar mengumumkan kepada orang banyak Abu Hurairah telah datang membawa uang dalam jumlah besar.

${ }^{22}$ Nazori Majid, Pemikiran Ekonomi Abu Yusuf Relevansinya Dengan Ekonomi Kekinian, (Yogyakarta: PSEI, 2003). hlm. 187.
} 
keuangan, militer dan pekerja. ${ }^{23}$ Sehingga dapat dikatakan bahwa sebenarnya diwan adalah lembaga bagian dari Baitul mal yang mengurusi/mengatur pemasukan serta penyaluran dana untuk pengurus tunjangan serta jaminan sosial kepada yang berhak dengan ketentuan yang sudah ditetapkan sesuai yang tertulis dalam arsip-arsip (kumpulan buku). Dalam salah satu pidatonya, yang dicatat oleh Ibnu Katsir ${ }^{24}$ tentang hak seorang khalifah dalam Baitul mal Umar berkata: “Tidaklah dihalalkan bagiku dari harta milik Allah ini melainkan dua potong pakaian musim panas dan sepotong pakaian musim dingin serta uang yang cukup untuk kehidupan sehari-hari seorang diantara orang-orang Quraisy biasa, dan aku adalah seorang biasa seperti kebanyakan kaum muslimin." 25 Umar juga memberikan konsep dalam kebijakan ekonomi bahwa "tidak ada prioritas dan keistimewaan seseorang atas hak orang lain dalam distribusi harta negara, seseorang dengan senioritasnya, seseorang dengan kekayaannya dan seseorang dengan kebutuhannya" ${ }^{26}$

Pemasukan harta Baitul mal pada masa Umar bin Khatab diklasifikasikan menjadi beberapa bagian sesuai jenis hartanya, yaitu: Zakat ; jenis harta yang masuk ke Baitul Mal terdiri dari jenis zakat uang (emas dan perak) dan perdagangan, zakat pertanian dan buahbuahan, dan zakat ternak (unta, sapi dan kambing). Umar bin Khatab mengirim para petugas pengumpul zakat ke seluruh penjuru negeri kekuasaan Islam setelah jumlah pemeluk Islam bertambah banyak. Umar membuat berbagai kebijakansaan, yaitu dengan menambah jenis barang yang dizakati bila dirasa perlu dan menghilangkannya jika dianggap sudah tidak relevan lagi.

Contohnya pada masa Rasulullah kuda merupakan binatang yang digunakan sebagai alat transportasi untuk pribadi dan berperang. Pada perang Badar pasukan kaum muslimin yang berjumlah 313 orang hanya memiliki dua ekor kuda. Jumlah kuda pada masa Rasul ini tidak mengalami peningkatan yang signifikan sehingga tidak ditetapkan zakat bagi pemilik kuda. Namun pada masa khalifah Umar, kegiatan berternak dan memperdagangkan kuda dilakukan secara besar-besaran di Syiria dan wilayah-wilayah kekuasaan Islam lainnya, maka diberlakukan zakat atas kuda-kuda tersebut. Kharaj akan tetap dikenakan non-muslim walaupun selanjutnya ia memeluk Islam. Pajak seperti ini dibebabankan atas tanah tanpa membedakan apakah pemiliknya anak-anak atau dewasa, orang merdeka atau budak, dan laki-laki atau perempuan. ${ }^{27}$ Kharaj pada mulanya ialah pajak tanah yang dipungut dari non-

${ }^{23}$ Sami bin Abdullah al-Maghlout, Jejak Khulaur Rasyidin 2 Umar bin Khatab, (Jakarta:Almahira, 2014), hlm. 384.

${ }^{24}$ Ibnu Katsir adalah penulis sejarah dan Mufasir (700-774 H/1300-1373)

${ }^{25}$ Gusfahmi, Pajak Menurut Syariah. (Jakarta: PT Raja Grafindo, Persada, 2008), hlm. 71.

${ }^{26}$ Mohammad Hidayat, The Sharia Economic... hlm. 20.

${ }^{27}$ Mahmud Irfan Raana, Sistem Ekonomi Pemerintahan Umar, (Jakarta: Pustaka Firdaus). hlm. 118119. 
Muslim ketika Khaibar ditaklukan. ${ }^{28}$ Kharaj ada yang dinamakan kharaj unwah ${ }^{29}$ (kharaj paksa) dan ada pula kharaj sulhi (kharaj damai). ${ }^{30}$

Contoh dari kharaj unwah adalah tanah di Irak, Syam, dan Mesir. Khalifah Umar bin Khatab menjadikan dalil surah a-Hasyr ayat 7-10 untuk peniadaan pembagian tanah Irak, Syam dan Mesir kepada pasukan tentara setelah Bilal, Abdurrahman, dan Zubair menuntutnya untuk membagikan tanah yang telah diberikan Allah seperti yang dilakukan Rasulullah dengan membagikan tanah Khaibar pada pasukan tentara yang turut dalam pembebasannya. Kemudian khalifah Umar menggunakan ayat tersebut untuk disampaikan kepada orang-orang Anshar yang dikumpulkan untuk dimintai pendapatnya. Mereka sepakat agar tanah tersebut (tanah di Irak) diberikan kepada Usman bin Hunaif untuk diukur batas tanah di Sawad yang ternyata mencapai 150 juta jarib serta memberikan batas kharaj dan memberikan laporannya kepada Umar. Kemudian Khalifah Umar menentukan beban kharaj kepada tanah sawad. ${ }^{31}$

Sebelum khalifah Umar wafat, dari tanah hitam yang subur di Kuffah telah diperoleh 100 juta dirham. ${ }^{32}$ Umar mengatur adsministrasi kharaj dengan mendirikan diwan al-kharaj dan harta kharaj sepenuhnya milik Bait al-mal. Umar amat teliti mengenai jumlah kharaj yang dibebankan kepada para petani, misanya Umar melarang petugas pajak tanah untuk memungut melebihi kemampuan wajib pajak sambil memperthatikan luas tanahnya. Kharaj hanya dibayar sekali dalam satu tahun kendati lahan yang dimiliki warga negara Madinah bisa ditanami dan di panen lebih dari satu dalam setahun. Sehingga pajak dari kharaj tidak menjadi beban yang memberatkan bagi masyarakat non-muslim yang berada dibawah pemerintahan Islam. Kharaj ini muncul seiring dengan terjadinya perdamaian yang disepakati antara kaum muslimin dan pemilik tanah (orang kafir). Jika penaklukan melalui perdamaian maka penduduknya tetap diperbolehkan tinggal. Jika perdamaian tersebut menetapkan bahwa tanah menjadi milik mereka (kaum kafir), dan tetap dikelola oleh mereka serta dibuat tanda kharaj yang diwajibkan atas mereka maka kharaj ini serupa dengan jizyah yang akan

${ }^{28}$ Muhammad, Kebijakan Fiskal dan Moneter dalam Ekonomi Islam, (Jakarta: Salemba Empat, 2002). hlm. 183.

${ }^{29}$ Kharaj unwah adalah kharaj yang di ambil dari seluruh tanah yang di kuasai kaum muslim dan diperoleh dari orang-orang kafir secara paksa melalui peperangan. Contohnya adalah tanah Irak, Syam dan Mesir.

30 Kharaj sulhi adalah kharaj yang di ambil dari setiap tanah dimana pemiliknya telah menyerahkan diri kepada kaum muslim berdasarkan perjanjian damai.

31 Sawad adalah nama sebuah nama di Irak dan menjadi bagian dari wilayah kekuasaan negara Islam pada periode Khalifah Umar bin Khatab

${ }^{32}$ Abdul Qaddim zallum, Sistem Keuangan Negara Khilafah, (Jakarta: HTI Pres, 2008). hlm. 55-57 
terhapus dengan masuknya mereka ke dalam Islam atau mereka menjualnya kepada orang muslim.

Apabila tanah kharaj dijual kepada orang kafir, maka statusnya sebagai tanah kharaj tetap tidak hilang, karena orang-orang kafir juga membayar kharaj dan jizyah. Pendapatan kharaj pada masa Umar besar jumlahnya, kharaj dari Irak berkisar 86.000.000 dirham setiap tahunnya dan mengalami peningkatan pada tahun berikutnya menjadi 100.020.000 dirham. Sedangkan dari wilayah Mesir jumlah kharaj berjumlah 12.000.000 dirham setiap tahunnya. ${ }^{33}$ Pendapatan Baitul mal dapat mencapai 160.000.000 dirham dari pajak tanah setiap tahunnya. Pemungutan kharaj terhadap setiap lahan pertanian tidak sama, Umar memungut kharaj berdasarkan pada tingkat kesuburan tanah, lokasi, dan lingkungan tempat tanah itu berada. Rate of Kharaj masa Umar bin Khatab, anggur dan kurma 10 dirham, tebu 6 dirham, alfafa (makanan kuda dan sapi) 5 dirham, gandum 4 dirham, dan jelai 2 dirham. ${ }^{34}$

Kemudian dari kharaj diambil gaji untuk para pegawai dan tentara, untuk berbagai santunan, biaya memperbanyak pasukan, mempersiapkan persenjataan, membiayai para janda, dan orang-orang yang membutuhkan untuk terwujudnya kemashahalatan. Jizyah adalah pajak yang telah dibebankan kepada orang-orang non-muslim yang menetap di bawah kekuasaan pemerintahan Islam. Pajak jizyah lebih berupa pengganti (kopensasi) bagi perlidungan yang diberikan kepada non-muslim atas keluarga dan harta miliknya oleh negara Madinah (kaum muslim). Ketentuan jizyah ini berdasarkan surah at-Taubah ayat 29. Jizyah juga sebagai pajak pengganti tugas kemiliteran, karena orang-orang non-muslim yang menjadi warga negara Madinah dibebaskan dari tugas kemiliteran (perang). Jadi pihak pembayar jizyah ini adalah orang-orang Yahudi dan Nasrani baik orang Arab maupun nonArab.

Khalifah Umar juga mengambil jizyah dari selain orang ahli kitab seperti Majusi Persia seperti Rasulullah mengambil jizyah dari orang Majusi Hijir. Seperti yang telah di jelaskan oleh Abu Ubaid al-Qasim; Dari Syihab bahwa Rasulullah mengambil jizyah dari orang-orang Majusi Hajr, Umar juga telah mengambil jizyah dari orang Majusi Persia dan Utsman telah mengambil jizyah dari Majusi Barbar. ${ }^{35}$ Khalifah Umar tidak membebankan jizyah kepada kaum wanita, anak-anak, orang-orang miskin, para budak dan rahib-rahib. Pemerintahan khalifah Umar sangat berlaku lemah lembut terhadap orang-orang miskin dan lemah, namun bersikap

\footnotetext{
33 Irfan Mahmud Raana, Sistem Ekonomi Pemerintahan Umar... hlm. 126

34 Nurul Huda dkk, Keuanagan Publik Islam Pendekatan Teoritis dan Sejarah, (Jakarta: Kencana Prenada Gurp, 2012). hlm. 132

35 Abu Ubaid al-Qasim, Kitab Al-Amwal, terjemahan Setiawan Budi Utomo, (Jakarta:Gema Insani, 2006). hlm. 98
} 
keras terhadap orang-orang kaya agar mereka tidak menghindar dari kewajiban membayar jizyah. ${ }^{36}$ Jizyah juga tidak diwajibkan atau dibebaskan atas orang yang memeluk Islam. Tapi jizyah tidak gugur karena kematian. Jika seseorang mati pada saat jatuh tempo membayar jizyah setelah setahun, maka ia tetap wajib membayar jizyah, karena dianggap hutang. Membayarnya menggunakan harta peninggalan.

Sedangkan pembebasan pembayaran jizyah untuk orang-orang lemah dan miskin pada masa khalifah Umar, dilatarbelakangi dari peristiwa ketika khalifah Umar berkunjung ke suatu tempat dan menjumpai seorang yahudi buta meminta-minta karena kewajiban membayar jizyah,dan kebutuhan ekonomi. Setelah itu Umar memerintahkan petugas Baitul mal untuk membebaskan orang-orang non-muslim yang lemah dan miskin dari kewajiban membayar jizyah dan menetapkan bantuan bagi mereka setiap tahun dari Baitul mal.37

Perbedaan pengaplikasian jizyah pada masa Umar dengan masa Rasulullah dan Abu Bakar terletak pada besarnya jumlah jizyah yang harus dibayar oleh non-muslim. Pada masa Rasul dan Abu Bakar jizyah hanya di ambil satu dinar dari ahlu dzimah. Pada Masa Khalifah Umar pembayaran jizyah bagi setiap orang dalam setahun berbeda. Penduduk Syam dan Mesir yang kaya membayar 4 dinar, 2 dinar untuk kelas menengah dan bagi orang miskin sebesar 1 dinar. Untuk penduduk Irak diwajibkan membayar 48 dirham bagi yang kaya. 24 dirham bagi yang menengah, dan 12 dirham bagi yang miskin bepenghasilan. ${ }^{38}$ Ghanimah adalah segala sesuatu yang dikuasai oleh kaum mulim dari harta orang kafir melalui peperangan di medan perang.

Harta tersebut bisa berupa uang, senjata, barang-barang dagangan, bahan pangan dan lain-lain. Ghanimah juga dapat diartikan sebagai harta yang diperoleh dari orang-orang kafir dengan melalui pertempuran. Ghanimah telah Allah tetapkan wewenang pendistribusian dan pengalokasiannnya kepada penguasa kaum muslim (khalifah). Harta ghanimah ini seperlima menjadi milik Allah dan Rasulnya, maksudnya: seperlima dari ghanimah itu dibagikan kepada Allah dan Rasul-Nya, kerabat Rasul (Bani Hasyim dan Muthalib), anak yatim, fakir miskin, dan ibnu sabil. Pada masa Rasulullah, ghanimah secara langsung alokasikan oleh Rasulullah sendiri. Alokasi harta ghanimah harus didasarkan pada pendapat khalifah dengan pertimbangan kemashahalatan kaum muslim. Khalifah Umar bin Khatab pernah memberikan

${ }^{36}$ Irfan Mahmud Raana, Sistem Ekonomi Pemerintahan Umar... hlm. 100-101

37 Afzalur Rahman, Doktrin Ekonomi Islam, judul asli "Economi doctrines of Islam Jilid 1, diterjemahkan oleh Soeroyo dan Nastangin, (Yogyakarta: PT Dana Bhakti Wakaf, 1995). hlm. 174-175

${ }^{38}$ Besarnya dinar yang ditetapkan oleh khalifah Umar sebagai jizyah atas orang dari ahlu dzimah dengan ukuran gram yang dapat diganti dengan emas pada saat ini adalah sebagai berikut: golongan kaya 4 dinar sama dengan 17,00 gram, golongan menengah 2 dinar atau 8,50 gram dan golongan miskin berpenghasilan 1 dinar atau setara 4,25 gram. 
harta ghanimah sebanyak sepertiga kepada Jarir bin Abdullah al-Bajilly serta sukunya setelah mengambil seperlimanya dari tanah hitam (tanah di Irak).

Khalifah Umar menganjurkan Jarir untuk terlebih dahulu pergi ke Irak beserta sukunya dan makan dari sepertiga tanah subur yang diberikan oleh khalifah Umar selama dua atau tiga tahun. Kemudian memintanya kembali untuk diberikan kepada kaum muslim yang sangat membutuhkan dengan memberikan Jarir 80 dinar. ${ }^{39}$ Pembagian ghaminah yang telah dilakukan oleh Rasul dan khalifah menunjukan bahwa ghanimah menjadi wewenang pemimpin untuk membagikannya dengan pertimbangan akan memberikan kebaikan bagi Islam dan kaum muslim. Harta ghanimah diperbolehkan dibagikan kepada pasukan yang ikut berperang dan juga di simpan dalam Baitul mal disatukan dengan harta fai', kharaj dan jizyah untuk dibelanjakan dalam rangka kemashalatan kaum muslim.

Dengan demikian hukum ghanimah sama dengan hukum harta, kharaj, jizyah, dan usyur yaitu disimpan dalam Baitul mal dan dibelanjakan memenuhi dan memelihara kebutuhan untuk kemashalatan kaum muslimin. Fai' adalah harta rampasan yang diperoleh dari musuh tanpa terjadinya pertempuran. Orang kafir memberikan fai' dengan harapan kaum muslim berbuat baik kepada mereka dan tidak memeranginya dengan menyerahkan tanah dan harta benda. Harta rampasan perang merupakan sumber pendapatan negara yang fungsinya tidak kalah penting dengan sumber-sumber pendapatan lainnya. Apapun jenis harta rampasan perang harus dibagikan sesuai dengan aturan yang telah berlaku sejak masa Rasulullah. Pada masa khalifah Umar, tanah-tanah yang berasal dari fai' sangat luas sehingga selanjutnya tanah-tanah tersebut dikuasai oleh negara namun penduduknya diberikan hak untuk mengelola dengan sewa tanah.

Khalifah Umar tidak membagi-bagikan tanah-tanah fai' dikarenakan kekhwatirannya mengenai timbulnya kesejahteraan yang tidak merata. Usyur merupakan hak kaum muslim yang diambil dari harta serta perdagangan ahlu dzimmah dan penduduk Harbi yang melewati perbatasan negara khalifah. Secara etimoligi usyur berarti sepersepuluh. Secara terminologi usyur berarti pajak yang dikenakan terhadap barang dagangan yang masuk ke negara Islam. Usyur diistilahkan oleh pajak perdagangan ataupun disebut bea-cukai pada masa sekarang. Pajak perdagangan ini mulai di kenal sejak masa khalifah Umar bin Khattab. Latar belakang penerapan usyur ini terjadi karena pada masa Umar berdasarkan laporan Musa al-Asyari bahwa para pedagang muslim yang berdagang ke wilayah non-muslim dipungut pajak perdagangan oleh pemerintah wilayah setempat.

${ }^{39}$ Abdul Qaddim Zallum, Sistem Keuangan Negara Khilafah, hlm. 45 
Demi menegakkan keadilan dan kesetaraan dalam perdagangan internasional Umar bin khatab pun memtuskan memungut pajak dari orang-orang non-muslim yang berdagang di wilayah Islam. Penduduk yang pertama kali di pungut usyur adalah kafir Harbi. Dalam menerapkan usyur, khalifah menunujuk petugas yang berwenang untuk memungut usyur dengan mendirikan lembaga Thaifah al-Usyur. Lembaga ini bertugas memungut usyur dan memberi sertifikat kepada mereka yang telah melunasi usyur ataupun memberi sanksi kepada mereka yang enggan membayar. Pemungutan tersebut dilakukan oleh Ziyad bin Hudair seperti diceritakan oleh Abu Ubaid al-Qasim dalam kitab al-amwal sebagai berikut: Dari Ziyad bin Hudair, ia berkata, "saya telah dilantik Umar menjadi petugas cukai. Lalu dia memerintahkan supaya mengambil cukai barang impor dari para pedagang kafir harbi sebanyak usyur, barang impor pedagang ahli dzimah sebanyak seperlima, dan barang impor pedagang kaum muslimin sebanyak seperempat dari usyur. ${ }^{40}$

Dalam pemungutan usyur ini, Umar bin Khatab selalu mempertimbangkan dua hal, yaitu barang-barang yang dikenakan usyur hanya barang perdagangan dan nilainya 200 dirham. Usyur dipungut atas seluruh jenis barang dagangan, misalnya perhiasan, hewan, hasil pertanian dan buah-buahan dan apabila perdagangan mereka melewati perbatasan negara serta dipingut setahun sekali. Kadar usyur yang dipungut 20 dinar untuk emas dan 200 dirham untuk perak. ${ }^{41}$ Kadar usyur tingkat perdagangan berkisar dari 2,5 pertahun untuk pedagang muslim, 5\% untuk ahlu zimmah dan 10\% untuk untuk para pedagang kafir harbi. Kadar usyur yang dipungut mencapai 20 dinar $^{42}$ Dalam memperlakukan ketentuan usyur Umar menerapkan prinsip keadilan. Besarnya pungutan usyur pada kafir dzimmi dan kafir Harbi merupakan wewenang khalifah dengan perlakukan seimbang.

Khalifah Umar mengenakan usyur kepada pedagang kafir Harbi jika mereka mengambil usyur kepada pedagang muslim di negeri mereka. Khalifah Umar juga melarang para petugas pajak untuk mengambil usyur lebih dari satu kali dalam setahun. Pendapatan dari usyur ini didistribusikan untuk membayar dana pensiun, dan dana bantuan serta untuk menutupi biaya operasional adsministrasi, kebutuhan militer dan lainnya. Pemasukan lainnya yang ditetapkan sesuai dengan ketentuan syari'at yang mengaturnya dengan mempertimbangkan situasi dan kondisi adalah seperti pemasukan dari sumber lain yang tidak rutin. Sumber pemasukan Baitul mal yang tidak rutin di antaraya; harta peninggalan dari seseorang yang tidak memili ahli waris yang sah secara syariat, harta yang tidak diketahui pemiliknya seperti

\footnotetext{
40 Abu Ubaid al-Qasim, op, cit. hlm. 64

${ }^{41}$ Nurul Huda, op, cit hlm. 135

${ }^{42}$ Qadhi Abu Yusuf Ya'qub ibn Ibrahim, Kitab al-kharaj, (Beirut: Dar al-Ma'rifah, 1989). Hlm. 132-
} 133 
harta kaum musyrik yang melarikan diri, harta temuan yang tidak diketahui pemiliknya setelah diumumkan dan barang tambang dan harta karun yaitu barang yang didapat dari dalam bumi. Untuk mendistribusikan harta bait al-mal Umar bin Khatab membentuk beberapa departemen, seperti: diwan al-kharaj sebagai penghimpun dana kharaj, jizyah, fai' serta pembelanjaannya, diwan al-jund yang dikhususkan untuk mengatur kehidupan pasukan perang dan keperluan perang lainnya ${ }^{43}$, serta diwan al-rasail (lembaga administrasi, keseketariatan). ${ }^{44}$

Rincian pengeluaran Bait al-mal di masa khalifah Umar; pasukan dan veteran perang Badar adalah 5.000 dirham, orang yang datang setelah perang Badar sampai perjanjian Hudaibiyah sebesar 4.000 dirham, orang yang datang setelah perjanjian Hudaibiyah sampai akhir perang Riddah sebesar 3.000 dirham, orang yang ikut dalam penakhlukan Syam dan perang Qadasiyah sebesar 2.000 dirham, orang-orang yang bergabung setelah perang Qadasyiah di Irak dan perang Yarmuk di Syam sebesar 1.000 dirham dan yang turut hadir dalam perang Qadasiah dan perang Yarmuk namun tidak ikut perang sebesar 200-500 dirham. ${ }^{45}$ Untuk tunjangan kepala daerah, hakim dan pegawai perpajakan, Umar menetapkan upah harian, bulanan dan tahunan. ${ }^{46}$

Khalifah Umar adalah orang pertama yang menetapkan gaji hakim. Kepeduliannya terhadap lembaga kehakiman dan gaji yang mencukupi, telah membuat lembaga kehakiman menjadi lembaga yang mandiri dan jujur. Umar memberikan gaji kepada Salamah bin Rabi' ah al-Bahili pada tugas peradilan dalam setiap bulan sebanyak 500 dirham dari Baitul mal. ${ }^{47}$ Dalam masalah penetapan gaji Umar meminta pertimbangan kepada para sahabat (majelis Syura). Umar menetapkan tunjangan rinci, seperti di Kufah, gubernur Amr bin Ash mendapat tunjangan 600 dirham/hari, setengah daging domba, kepala, kulit, kakinya dan setengah ember makanan. Umar juga memberi hadiah buku-buku dan Mu'adzin. Khaliafah Umar mengirimkan satu ekor kambing/hari untuk Ammar bin Yasir, Utsman bin Hunaif (pengurus tanah) dan Ibn Mu'ud (qadhi dan petugas Baitul mal).

\footnotetext{
${ }^{43} \mathrm{Ahmad}$ Ibrahim Abu Sinn, Manajemen Syariah judul asli Al-Idarah fil Islam, penerjemah (Jakarta: PT Raja Grafindo, 2006), h. 103

${ }^{44}$ Ahmad Ibrahim Abu Sinn, Manajemen Syariah: Sebuah Kajian Historis dan Kontemporer, judul asli Al-Idarah fi Al-Islam terjemahan Dimyauddin Djuwaini, (Jakarta: PT Raja Grafindo, 2008), h. 43

45 Sami bin Abdullah al-Maghlout, op,cit, h. 388

46 Umar menetapkan jatah harian petugasnya di Kuffah berupa dua ekor kambing dan dua buah ember yang dipotong dan dimasak pagi dan sore, sementara kuah yang tertinggal di ember dijadikan minuman.

47 Jaribah bin Ahmad al-Haritsi, Fiqih Ekonomi Umar bin Khatab. Judul asli Al-Fiqih al-Iqtishadi li Amiril Mukminin Umar bin Khatab, terjemahan Asmuni Solihah Zamakhsyari, (Jakarta: Pustaka alKautsar, 2014), h. 240
} 
Pembangunan fasilitas umum, Umar juga memerintah Amr bin Ash agar menfaatkan 1/3 dari penerimaan Mesir untuk membangun jembatan, terusan dan jaringan suplai air. Gedung penampungan bahan makanan, tepung, jagung, anggur dan segala kebutuhan musafir dan tamu juga didirikan pada masa Umar. Khalifah Umar juga memperluas Masjid Nabawi . Pada waktu itu Masjid Nabawi berperan penting yaitu sebagai tempat sholat sekaligus pusat pemerintahan. Khalifah Umar juga mengganti Kiswah Ka'bah dengan kain Kibti berwarna putih. ${ }^{48}$ Pengadaan fasilitas umum lainnya adalah penggalian penghubung sungai Nil dan laut Merah dari samping Kota Fustat sampai ke laut Merah. Hal ini bertujuan memperlancar pengangkutan hasil bumi Mesir ke wilayah Arab yang sebelumnya butuh waktu lama menggunakan kuda dan unta. Proyek lain di masa Umar adalah pembangunan kota-kota perkampungan tentara. Setelah itu didirikan perumahan permanen dari bebatuan dan terus berkembang hingga menjadi kota "duta" peradapan Islam.

Untuk pembangunan kota-kota digunakan dana jizyah yang dipungut dari berbagai daerah, khususnya dari daerah itu sendiri. Selanjutnya untuk tebusan tawanan perang Ibnu Abbas meriwayatkan perkataan Umar: "setiap tawanan yang ada di tangan kaum musyrikin tebusannya diambil dari Baitul mal kaum muslimin". ${ }^{49}$ Sedangkan untuk jaminan social, jaminan ini berbentuk bantuan langsung buat orang-orang tertentu, selain ashnaf zakat, termasuk anak yatim, janda, orang, orang sakit, pengamanan dan korban bencana alam. ${ }^{50}$ Untuk bayi Islam yang lahir secara syar'i ataupun secara temuan, khalifah Umar memberikan tunjangan sebesar 100 dirham dan ketika mereka sudah beranjak merangkak jatahnya ditambah lagi menjadi 200 dirham. Ketika sudah mendekati usia baligh ditambah lagi 500 dirham atau 600 dirham. ${ }^{51}$

Seperti ketika sakit waja' (penyakit dalam) Muaiqib (bendahara Baitul mal) kambuh Umar memanggil dua orang dokter dari Yaman dan menyuruh mereka mengobatinya dan membayarnya dari harta Baitul mal. Pada waktu terjadi kelaparan di semenanjung karena kemarau yang melanda selama sembilan bulan khalifah Umar juga menggunakan harta Baitul mal Madinah. Gaji para guru (tenaga pendidik), khalifah Umar member gaji tiga tenaga pengajar yang mengajar anak-anak kecil di Madinah masing-masing 15 dinar perbulan. ${ }^{52}$

48 Pada masa jahiliyah Kiswah tersebut terbuat dari kulit binatang, nabi menggantinya dengan kain yang berasal dari Yaman dan Umar menggantinya dengan kain yang berasal dari Mesir.

49 Perkataan Umar yang lain:"Menyelamatkan satu orang kaum muslimin dari tangan kaum kafir, lebih aku sukai dari pada menguasai seluruh Jazirah Arab Quthub, h. 117-118

${ }^{50}$ Surtahman Kastin Hasan. Ekonomi Islam; Dasar dan Amalan (Dewan Bahasa dan Pustaka, 2001), h. 162

${ }^{51}$ Quthub Ibrahim Muhammad,op,cit h. 197-199

52 Taqyudin an-Nabhani, op,cit, h. 98 
Madrasah ilmiah tekemuka pada masa khalifah Umar bin Khatab adalah: madrasah di Mekah di pimpin oleh Abdullah bin Abbas sang "penafsir al-Qur'an".

Selain itu juga ada madrasah di Kuffah, Syam dan Mesir. ${ }^{53}$ Pos pengeluaran lain yang sudah menjadi salah satu jenis kegiatan Baitul mal adalah pinjaman kepada orang-orang yang membutuhkan. Dalam hal ini Istri Umar pernah meminjam uang satu dinar dari Baitul mal untuk membeli minyak wangi. Abdullah dan Ubaidah pernah diberi pinjaman berupa 1/5 ghanimah dari Irak guna modal usaha membeli dagangan untuk dijual di Madinah. Keuntunga usaha itu dibagi dua (1/2 untuk Abdullah dan Ubaidillah dan 1/2 lagi untuk diserahkan ke Baitul mal dan modal awal dikembalikan ke Baitul mal. Dari berbagai sumber pemasukan Baitul mal yang telah ada pada masa Umar dapat dipahami bahwa pengeluaran di distribusikan yang dilakukan sangat hati-hati. Kebijakan khalifah Umar dalam mendistribusikan pendapatan-pendapatan negara sangat mirip dengan kebijakan-kebijakan pokok yang harus ada di sistem negara kesejahteraan modern. Pendapatan negara oleh khalifah Umar digunakan untuk menciptakan skema-skema yang mengarah pada terwujudnya kesejahteraan sosial. Walaupun masalah-masalan yang dihadapi tak serumit permasalahan yang dihadapi oleh negara-negara modern saat ini, Namun secara cita-cita dalam nilai-nilai pemerintahan khalifah Umar telah mengarah pada model negara kesejahteraan.

\section{Manajemen Baitul Mal pada Masa Khalifah Umar bin Khattab}

James A.F. Stoner, R. Edwar Freeman dan Daniel R. Gilbert JR merumuskan fungsi manajemen dengan palnning, organizing, leading dan controlling. ${ }^{54}$ Ahmad Abu Sinn juga mengemukakan manajemen mempunyai empat fungsi yaitu palnning, organizing, leading dan controlling. ${ }^{55}$ Fungsi actuating sebagai penggerakan yang ditimbulkan oleh adanya pengaturan oleh pemimpin (leading) agar dapat dimengerti untuk tujuan yang telah tentukan. Jadi, actuating erat kaitannya dengan pemimpin. Jadi manajemen Bait al-mal merupakan proses membuat perencanaan, pengorganisasian, dan pengendalian/pengawasan berbagai pemasukan dan pengeluaran harta kaum muslimin yang ada di dalam Bait al-mal untuk mencapai sasaran yaitu kemashlahatan umat. Hal ini sesuai kaidah fiqih: "Tindakan yang dilakukan seorang imam (pemimpin) senantiasa mengacu kepada kemashalatan".

53 Abdul Qadim Zallum, op,cit. h. 403-404

${ }^{54}$ James A.F.Stoner, R.Edwar Freeman dan Daniel R. Gilbert JR., Management (New Jersey: Prentice-Hall, Inc.A. Simon \& Schuster Company, 1995), diterjemahkan oleh Alexander Sindoro, Managemen 1(Jakarta:PT Buana Populer.1996),h. 7

${ }^{55}$ Ahmad Abu Sinn, op,cit. h. 28-29. 
Baitul mal adalah rumah harta atau tempat penyimpanan harta dengan diwan sebagai lembaga bagian dari Bait al-mal yang mengurusi dan mengatur pemasukan serta penyaluran dana kepada yang berhak dengan ketentuan syariah dan ijtihad khalifah (ditetapkan sesuai yang tertulis dalam kumpulan arsip-arsip (diwan) tentang siapa saja yang berhak menerima tunjangan). Selain itu Khalifah Umar juga mengklasifikasikan pendapatan negara, hal dapat memudahkan distribusi penyaluran harta kaum muslimin agar tidak bercampur dengan harta-harta lainnya. Adanya diwan sebagai lembaga bagian dari Bait al- mal yang mengurusi atau mengatur pemasukan serta penyaluran dana bisa juga dikatakan lembaga pengurus tunjangan kepada yang berhak dengan ketentuan yang sudah ditetapkan oleh syari'at dan ijtihad menjadikan Bait al- mal dijalankan dengan administrasi yang baik dan permanen. Dengan adanya pengklasifikasian pendapatan dan pendistribusian kekayaan negara, Umar sudah menerapkan kemampuan manajerial sebagai seorang pemimpin (khalifah) dalam pengelolaan harta kekayaan negara. Manajemen dari penerimaan dan pendistribusian (termasuk pengelolaan harta) Bait al-mal dapat diketahui dengan jelas pada saat dilakukan berbagai tindakan nyata khalifah dalam penerimaan dan pendistribusian harta Bait al-mal, demi kesejahteraan rakyatnya.

\section{Perencanaan}

Perencanaan sebagai pengarah untuk meminimalisir pemborosan sumber daya dan penetapan standar pengawasan. Sehingga seorang pemimpin memikirkan terlebih dahulu tindakan dan sasaran yang ingin dilakukan berdasarkan rencana untuk mencapai tujuan. Perencanaan ekonomi pada masa khalifah Umar disesuai dengan situasi dan kondisi yang ada di lapangan pada masa itu (ekspansi yang luas). Ketika saldo keuangan negara mencapai jumlah yang sangat banyak, khalifah Umar menginginkan adanya perencanaan pembagian harta tersebut untuk rakyat yaitu dengan mendirikan Baitul mal dengan dilengkapi diwan melalui musyawarah dewan syura. Hal ini menunjukan bahwa khalifah Umar dan kaum muslimin pada masa itu umumnya senantiasa membuat perencanaan atas segala sesuatu yang akan dilakukan. Islam memang mengajarkan umatnya untuk membuat perencanaan yang matang dan itqan, karena setiap pekerjaan akan menimbulkan sebab akibat. Adanya perencanaan yang baik akan menimbulkan hasil yang baik. Beberapa kegiatan manajemen Umar bin Khatab terhadap harta yang masuk dalam Baitul-mal, yaitu: perencanaan yang terkait dengan pengelolaan Baitul mal dari sumber pemasukan negara, pengeluaran negara dan prinsip pendistribusiannya. 
Pengumpulkan data dan informasi untuk pengambilan keputusan apa yang akan dilakukan merupakan salah satu keahlian Umar dalam strategi manajemen informasi. ${ }^{56}$ Manajemen informasi ini telah dilakukan oleh khalifah Umar bin Khatab dalam rangka penetapan perkiraan kharaj di Irak tentang luas, cuaca, kesuburan, posisi tanah (menentukan biaya pengelolaan), dan kualitas tanaman. ${ }^{57}$ Tidak hanya di Irak tapi juga berlaku di tanah pertanian Syam dan Mesir juga diberlakukan kharaj. Keputusan Umar menjadikan tahah Irak ini menjadi tahan kharaj membuktikan bahwa khalifah Umar mempunyai perencanan ekonomi yang sangat matang untuk mensejahterakan rakyatnya dalam bentuk cadangan harta untuk keperluan masa depan rakyatnya (orang-orang sesudahnya). Perencanaan dari pengeluaran pada masa khalifah Umar disesuaikan dengan kondisi dan keadaan pada waktu itu, dengan beberapa pos pengeluaran yang telah di tetapkan.

Dalam pendistribusian khalifah Umar telah menetapkan bahwa semua harta Baitul mal seluruhnya dikelola dan diditribusikan berdasarkan ketentuan syariat, pendapat dan ijtihad khalifah sebagai pemimpin untuk hal-hal yang baik bagi kemashalahatan, karena khalifah adalah pemegang amanah dan harta Baitul mal dalah harta milik Umat. Sebagaimana dalam Islam melarang menumpuk kekayaan pada kelompok tertentu saja. Islam mengakui kesejahteraan individu dan kesejahteraan sosial masyarakat saling melengkapi satu dengan lainnya karena Islam mewujudkan kemanfaatan bersama. ${ }^{58}$

\section{Pengorganisasian}

Dalam setiap perencanaan yang telah ditetapkan perlu adanya pengorganisasian untuk menetapkan struktur peran. Pentingnya pengorganisasian telah di tegaskan dalam QS. alShaff ayat 4 yang artinya: "Sesungguhnya Allah menyukai orang yang berperang dijalan-Nya dalam barisan yang teratur seakan-akan mereka seperti suatu bangunan yang tersusun kokoh". Dengan adanya pengorganisasian, memungkinkan untuk mengatur sumber daya insani pegawai Baitul al-mal. Pada masa khalifah Umar bin khatab pemilihan para pegawai untuk menjalankan tugas berdasarkan kompetensi dan kemampuan yang dimiliki. Ketika khalifah Umar membentuk Bait al-mal beserta diwan-diwan menunjuk pada proses pengorganisasian yaitu bagaimana pekerjaan diatur dan dialokasikan diantara para anggota, dengan menunjuk serta menetapkan tugas para pegawai-pegawai Baitul-mal, seperti Abdullah bin Arqam

${ }^{56}$ Manajemen informasi adalah kegiatan mengumpulkan data dan pengembalian keputusan secara tetap dan cepat untuk menhindari terjadinya melesetnya waktu, kesalahan, dan terlewatnya kesempatan. Lihat Sigit Winarno dalam, Kamus Besar Ekonomi, (Bandung; Pustaka Grafika, 2010) h, 295

${ }^{57}$ Abdul Qidim Zallum dalam bukunya Al-Amwal fi Daulah Khilafah, terjemahan Ahmad. S (Jakarta; HTI Press, 2008) h. 62

58 Afzalurrahman, Economic Doctrines of Islam terj. Soeroyo dan Nastangin, Doktrin Ekonomi Islam, 1 (Yogyakarta: Darma Bakti Wakaf, 1995),h. 10 
sebagai kepala pajak yang dibantu oleh beberapa pegawai seperti pegawai tanah dan pegawai dalam bidang-bidang khusus untuk memungut pajak (termasuk zakat), kharaj, usyur. Abdurahmad bin Ubaid dan al-Qari dan Muaqib sebagai wakil-wakilnya.

Seperti diangkatnya Salman bin Rabi'ah al-Bahil sebagai petugas pembagi rampasan perang. Kemudian di setiap provinsi juga di dirikan Baitul mal dengan seorang pejabat yang bebas dari pengawasan amir atau gubernur.59 Kemudian diangkat pegawai perkatoran, petugas yang mengumpulkan harta dan membagikan harta rampasan perang kepada pasukan, juru tulis, sekretaris, pendata tentara, dan pengatur tunjangan,. Pengorganisasian ini memberikan kemudahan untuk pemberian tunjangan kepada yang berhak. Sehingga hal ini menjadi suatu bentuk pengorganisasian yang modern pada masa itu. Dalam lembaga Baitul mal juga diberikan ruangan khusus untuk penulis arsip (pembukuan). Penulisan arsiparsip dan adanya tempat-tempat tertentu yang dikhususkan untuk penyimpanannya serta ruangan untuk para penulisnya. ${ }^{60}$ Pengorganisasian lembaga Baitul mal ini memudahkan pemerataan distribusi ekonomi yang adil sehingga tujuan yang sebelumnya direncanakan seperti pembagian tunjangan atau santunan kepada yang berhak dapat mudah dilakukan. Khalifah Umar sebagai pemimpin mempunyai tanggung jawab besar untuk mearalisasikan rencana melalui penetapan kerja kepada pegawainya sesuai bidang dan keahliannya masingmasing sehingga pekerjaan yang dilakukan pegawai dapat terlaksana secara efektif dan efisien.

Khalifah Umar melakukan pembagian aktivitas sesuai dengan kemampuan dan kompentensi teknis yang dibutuhkan (penempatan kerja). Contohnya Umar menugaskan Utsman bin Hanif untuk melakukan pengukuran tanah di Irak, cara penetapan jumlahnya dan perhitungannya. Umar mengutus Utsman bin Hanif karena dia berpandangan luas, berakal kuat, dan berpengalaman. Penetapan Utsman bin Hanif juga berdasarkan musyawarah. ${ }^{61}$ Dalam hal ini khalifah Umar bisa dikatakan memanejemen sumber daya insani (manusia) sebelum menentukan aktivitas pegawainya. Dalam konsep umum pemilihan pegawai merupakan aktivitas kunci untuk menentukan jalannya sebuah perencanaan. Maka dari itu pemimpin harus selektif dalam memilih calon pegawai, yaitu harus mempunyai

${ }^{59}$ K. Ali, A, Studi Of Islam History, terj. Adang Affandi, Studi Sejarah Islam, (t.t, Bina Cipta, 1995), h. 157

${ }^{60}$ Abdul Qadim Zallu, op, cit, h. 22

${ }^{61}$ Umar berkata kepada mereka: karena hal ini adalah urusanku, maka adakah seorang laki-laki yang berakal kuat serta mampu menempatkan tanah pada tempatnya dan menempatkan hewan liar pada tempatnya? Mereka semua sepakat mengusulkan Utsman bin Hanif dan berkata: 'Serahkanlah kepadanya karena dia adalah seseorang yang berpandangan luas, berakal kuat dan berpengalaman'. Maka segerlah Umar menemuinya dan menyerahkan urusan pengukuran tanah subur Irak kepadanya. Lihat dalam Abdul Qadim Zallum, op,cit, h. 62. 
kompeten, pengetahuan luas, rasa tanggung jawab dan dapat di percaya. Khalifah Umar dalam memilih seorang pegawai senantiasa meminta pendapat dari para sahabat, bukan berdasar pendapat pribadi. Bahkan beliau berkata kepada para sahabat: "Berikanlah isyarat kepadaku, tunjukanlah kepadaku orang yang patut untuk aku jadikan pegawai..." Umar juga memberikan wasiat kepada Ali, Utsaman, dan Sa'ad bin Abi Waqqash, "Hai Ali, jika engkau mengangkat pemimpin untuk mengusrusi persoalan manusia, pilihan dari keluarga Bani Hasyim. Hai Utsman jika engkau mengangkat pemimpin untuk mengurusi persoalan manusia, pilihan dari keluarga Abu Mu'ith. Hal ini menunjukan khalifah umar sangat demokrasi dalam menetapkan sesuatu dan sangat memperhatikan kompetensi para pegawai.

\section{Pelaksanaan}

Dalam prespektif Islam actuating perlu adanya koordinasi agar upaya untuk mencapai hasil yang baik dan seimbang termasuk diantaranya langkah-langkah bersama untuk mengaplikasikan perencanaan dengan mengharapkan tujuan yang diidamkan dapat terwujud. Dalam actuating diperlukan leading atau pemimpin yang tak hanya memimpin tapi juga memberikan motivasi dan mengarahkan apa yang harus dilaksanakan oleh organnisasinya. Khalifah Umar melakukan penggerakan terhadap pegawainya untuk melakukan tugas dan tanggung jawabnya serta memberi pesan kepada gubernur dan pegawainya untuk rendah hati, berlaku adil, berakhlak mulia dan belas kasih kepada rakyat. Jadi leading dalam hal ini untuk memberikan semangat menjadi pelaku organisasi yang baik. Dengan kata lain yaitu memotivasi kepada pegawai untuk melaksanakan tugas dengan baik. Pesan melalui surat ini adalah termasuk perhatian Umar terhadap pegawainya agar selalu melaksanakan tugas dan tanggung jawab.

Surat Khalifah Umar bin Khatab kepada Abu Musa; Sesungguhnya kekuatan itu terletak dalam bentuk perbuatan. Janganlah engkau memperlambat pekerjaan hari ini hingga esok hari. Sebab apabila kamu melakukan yang demikian itu, maka seluruh pekerjaan akan semakin terus menumpuk. Akibatnya kamu tidak mengetahui lagi, manakah pekerjaan yang harus di mulai. Dengan demikian, kamu akan membuang-buang waktu dan menyia-nyiakannya. Sesungguhnya segala pekerjaan itu akan tetap dapat dilakukan oleh seseorang pemimpin selama dia menunaikan tugas dan kewajiban terhadap Allah. Apabila seorang pemimpin berfoya-foya dan terlena, maka rakyat pun akan melakukan demikian. Pada saat itu, umat akan merasa benci terhadap pemimpin mereka. Aku selalu meminta perlindungan kepada Allah supaya diriku tidak mengalami yang demikian itu (atau dia mengatakan; supaya diri kami tidak mengalami yang demikian itu). Sebab yang demikian itu merupakan kedengkian yang terpendam, 
keduniaan yang diagung-agungkan, dan hawa nafsu yang di dewa-dewakan. Oleh karena itu, tegakkanlah kebenaran walaupun hanya sebentar saja.62

Surat ini menunjukan bahwa umar memanjemen setiap pelaksana kegiatan dengan memberikan nasehat dan motivasi yang berkaitan dengan nilai-nilai keimanan dan ketauhidan. Khalifah Umar juga memuji kepada pegawainya yang berbuat baik bahkan memecat pegawai yang tidak berlaku baik. Khalifah Umar pernah memecat Khalid bin Walid (pimpinan militer Syam yang di ganti Abu Ubaidah pada tahun $13 \mathrm{H}$ ) dari jabatnnya, bukan karena tidak mengakui kejeniusan Khalid sebagai pemimpin militer Syam. Namun karena hal tertentu yang membuat khalifah Umar kecewa. Dalam konteks sejarah diceritakan bahwa Khalid membagikan harta rampasan perang kepada kepada orang-orang kuat, bangsawan dan ahli bersilat lidah. ${ }^{3}$

Sebagai seorang pemimpin khalifah Umar juga terkenal dengan suri tauladan yang baik (uswah hasanah) bagi rakyatnya. Umar sangat perhatian terhadap persoalan rakyatnya, memberikan nasehat ketika mereka melakukan kesalahan dan memberikan semangat (motivasi) jika mereka melakukan kebenaran. Memberikan argument kepada rakyat secara bijaksana sehingga mereka merasa nyaman dengan pendapatnya. Berkaitan dengan Baitul mal dalam fungsi kepemimpinan yang telah dilakukan oleh Umar bin Khatab adalah mengimplementasikan pembimbingan dan pemberian motivasi kepada para pegawainya agar bekerja dengan efektif dan efisien dalam pencapaian tujuan dari adanya Baitul mal sebagai lembaga yang independen.

Tidak hanya itu saja, beliau juga memberikan tugas dan penjelasan mengenai pekerjaan dan kebijakan yang ditetapkan. Dalam hal ini Umar sebagai seorang pemimpin mampu mengarahkan dan memimpin anggota, percaya diri, berjiwa besar, memahami orang lain dan memiliki obsesi yang kuat terhadap tujuan yang ingin dicapai. Kemampuan strategis dalam perekonomian ini pernah dijalankan oleh Umar yaitu ketika tanah kharaj di Irak, Syam, dan Mesir tidak dibagikan kepada pasukan denga alasan bahwa untuk kemakmuran kaum muslimin yang akan datang dikelola oleh negara untuk rakyatnya berdasarkan pendapat dan ijtihadnya. Dengan demikian dapat dikatakan bahwa khalifah Umar memiliki jiwa seorang pemimpin muslim atau manajerial yang mumpuni bahkan mempunyai kemampuan strategis, kebijakan atau program-program pada masa pemerintahannya untuk mewujudkan kemshalahatan rakyatnya.

\footnotetext{
62 Abu Ubai al-Qasim,op,cit. h. 63

${ }^{63}$ Sami al-Maghlout, op, cit, h. 230.
} 


\section{Melakukan Pengawasan Harta}

Dibentuknya lembaga Baitul mal yang independen yang jauh dari nintervensi pemerintahan menjadi keberhasilan dalam pengawasan harta. Independensi Baitul mal dan konsistensi khalifah Umar sangatlah penting untuk melindungi Baitul mal dari penyimpangan penguasa, jangan sampai seorang penguasa menganggap bahwa dirinya yang berkuasa dan dengan seenaknya bertindak seperti pemilik barang mengambil harta sesuai dengan kehendaknya dan memberikannya kepada siapapun yang dikehendaki tanpa memperbolehkan seseorang untuk mengawasinya apalagi mengaturnya (tidak dapat membedakan harta pribadi dan milik negara).

Dalam prinsip manajemen Islam, pengawasan tidak hanya dikenal dengan pengawasan yang bersifat eksternal yaitu pengawasan dari orang lain baik atasan atau rakyat umum terhadap orang yang diberi kepercayaan semata, tetapi juga mengedepankan pengawasan internal. Pengawasan yang bersifat internal muncul dari adanya tanggung jawab seorang idividu untuk bersikap amanah dan adil dalam setiap pekerjaan yang diembannya. ${ }^{64}$ Pada hakekatnya harta Baitul mal adalah kepunyaan Allah. Pemerintah dan pegawainya hanya dipercaya untuk memelihara dan menyampaikan kepada yang berhak. Namun bukan berarti khalifah dan pejabat yang berwenang membiarkan bawahannya melakukan apapun terhadap harta tersebut. Mereka tetap dituntut untuk melakukan pengawasan kalau terjadi kesalahan dalam penunaian hak atau ada yang sengaja menyelewengkan kepercayaan yang diberikan. Khalifah Umar pernah berkata bahwa "barang siapa yang menjaganya, berarti dia telah menjaga urusan umat Islam dan barang siapa yang menyia-nyiakannya berarti dia telah menyia-nyiakan umat Islam".

Pengawasan internal dalam hal ini adalah menunaikan amanah merupakan kewajiban setiap muslim, bersungguh-sungguh dalam pekerjaannya, melakukan evaluasi sebelum dievaluasi orang lain dan meyakini Allah senantiasa mengawasi segala aktivitasnya. ${ }^{5}$ Dalam hal ini yusuf Qaradhawi pun menekankan menurutnya persoalan yang sangat mendasar dalam ekonomi Islam adalah pengawasan yang bersifat internal yang ada dalam hati nurani dan tumbuh dari rasa keimanan seorang muslim. Yang menjadi pengawas disini adalah diri pribadi, hati nuarni seorang muslim tidak akan mengizinkan dirinya untuk mengambil yang bukan haknya ataupun memakan harta orang lain dengan cara yang batil. ${ }^{66}$ Umar bin Khatab mengingatkan untuk membiasakan hidup zuhud dan iffah (keterjagaan) dari penyelewengan.

\footnotetext{
${ }^{64}$ Ahmad Ibrahim Abu Sinn, Op,cit,h. 120

${ }^{65}$ Rozalinda, Manajemen Waqaf Produktif, (Jakarta:RajaGrafindo Persada, 2015),h. 85

${ }^{66}$ Yusuf al-Qaradhawi, "Malamih al-Nujtama al-Muslim allazi Nansyuduh, (kairo maktabah Wabah, 1993), hl. 36
} 
Untuk itu para pegawai ditutut untuk selalu bertanggung jawab, amanah dan adil dalam setiap pekerjaan yang diembannya.

Sedangkan untuk pengawasan eksternal khalifah Umar Bin Khatab memberlakukan penghitungan kekayaan calon pegawai (terutama gubernur) yang akan diangkat. ${ }^{67}$ Ketika tugasnya sudah berakhir hartanya dihitung kembali. Jika ditemui kelebihan (yang tidak bisa dipertanggungjawabkan) maka dikembalikan ke Baitul mal.68 Penarikan harta harus dilakukan dengan cara yang adil tanpa melakukan kezaliman terhadap pemilik harta. Hal ini menunjukan bahwa pengawasan sektor keuangan Negara dilakukan, sehingga perlindungan aset publik menjadi bagian pengawasan untuk menghindari dari praktek korupsi dan penggelapan uang. Sebagai seorang pemimpin pengawasan khalifah Umar ditunjukan dengan sikap cermat dan selalu konsen terhadap kehidupan pegawai, pejabat dan rakyatnya dengan sebaik mungkin. Memperhatikan perilaku dan kinerja mereka agar tidak menyianyiakan kehidupan rakyat.

Hal ini dilakukan oleh khalifah dengan berkelana berkeliling di kampung-kampung untuk meneliti kehidupan rakyatnya. Khalifah Umar selalu berpesan agar pegawainya hidup sederhana. Dalam hadist riwayat Ibn Sa'ad dalam Ismail bin Umar bin Asy-Syafi'i (al-Imam Ibnu Katsir w:700 H) Umar berkata: "Harta yang dikaruniakan Allah tidak halal bagiku selain dua helai baju, satu baju untuk musim dingin dan baju lainnya untuk musim panas, makanan keluargaku sama seperti makanan orang qurays pada umumnya, makanan biasa bukan makanan orang-orang kaya. Selebihnya aku hanya salah seorang muslim". 69 Sehingga dapat dipahami bahwa pada masa khalifahan Umar sudah terdapat pengawasan eksternal terhadap kinerja pegawai publik untuk menjaga penduduk (rakyat) dari tindak kezaliman dan kewenangan pegawai pelayanan publik baik di lembaga Baitul Mal maupun di lembaga pemerintahan.

Pengawasan pengeluaran harta Baitul mal adalah sebab utama dibuatnya diwan (buku/arsip) tersebut. Ide tentang diwan sebenarnya datang dari Persia dan Romawi yang mempunyai buku untuk menentukan jumlah pajak dan cara mengumpulkannya. Namun demikian patut dicatat bahwa khalifah Umar melakukan ini untuk mengambil pelajaran darinya dalam menentukan dan mengumpulkan harta pajak yang menjadi hak umat Islam atas harta ahlu dzimmah. Diwan tersebut juga mengatur urusan tanah kharaj dengan menjelaskan luasnya dan jumlah kharaj yang ditentukan, menjelaskan hukumnya dan lain

\footnotetext{
${ }^{67}$ Abbas Mahmud Al-Akad, Abaqariayu Umar, terj Gaziroh Abdi Ummah, Kejeniusan Umar, (Jakarta: Pustaka Azam, 2002), h. 104

${ }^{68} \mathrm{Amr}$ bin Ash yang mempunyai kekayaan agak lumayan dan akhirnya Umar mengutus Muhammad bin Maslamah untuk memeriksa dan membagikannya.

${ }^{69}$ Ismail bin Umar bin Asy-Syafi'i (al-Imam Ibnu Katsir w:700 H), Al-Khulafa al-Rasyidun 2, terjemahan Umar Mujtahid, (Jakarata: Perisai Qur'an, 2012), h. 29
} 
sebagainya. Diwan ini selain ada di Madinah juga ada dicabang (provinsi) dan tidak bisa dipungkiri keberadaan diwan sangat mempermudah menghitung pemasukan dan juga mempermudah pengeluaran. Sedangkan cara yang dilakukan Umar dalam mengawasi pengeluaran harta Baitul mal adalah sebagai berikut.

Pertama, mensensus orang yang berhak mendapat gaji dan mendaftarkan namanya dalam buku tersebut untuk memastikan siapa yang sudah dan belum menerima haknya, sehingga tidak ada seorangpun yang luput untuk mendapatkan haknya disamping untuk menghindari memperoleh bagian yang lebih. Kedua, khalifah Umar membatasi gaji dengan jumlah batasan pertahun yang tetap dimana ditetapkan bagi setiap orang jumlah gajinya dari Baitul mal sesuai dengan dasar ketentuan yang berlaku. Pendistribusiannya gaji diberikan kepada pemimpin wilayah/ gubernur kemudian mereka memberikannya kepada yang berhak dalam wilayahnya tersebut (desentralisasi).

Ketiga, untuk menjamin sampainya hak kepada pemiliknya, khalifah Umar memiliki aturan untuk memilih para pemimpin, dan penjaga Baitul mal. Dengan adanya diwan tersebut tidak bisa dipungkiri telah memberikan kemudahan dalam mengontrol arus kas, baik pemasukan maupun pengeluaran serta menjadikan sumber pemasukan lebih terkontrol begitu juga pengeluarannya yang dimudahkan dengan perhitungan tahunan. Bagi yang melakukan peyelewengan dalam mengelola Baitul mal akan dikenakan sanksi. Seperti perlakuan Mu'aim bin Zaid pernah memalsukan stempel Baitul mal dan kemudian ia berhasil mengumpulkan harta kharaj dari kufah (Irak). Ketika hal ini diketahui oleh khalifah Umar, maka khalifah minta pendapat orang banyak tentang hukuman yang akan diberikan.

Maka diberikan hukuman cambuk, kemudian dipenjarakan sampai insyaf. Sanksi ukhrawi terhadap para pelaku pengkhianat dalam pemanfaatan harta negara juga telah dijelaskan Allah dalam QS. Ali Imran ayat 161. Ancaman ukhrawi jauh efektif dari pada sanksi duniawi. Kewajiban negara atas rakyatnya adalah melayani dan mengurusi urusan umat, karena seorang pemimpin pasti kelak akan ditanyakan atas kepemimpinannya. Salah satu urusan umat yang wajib dilaksanaknnya oleh negara adalah mengatur ekonomi dengan tujuan meningkatkan kesehjahteraan rakyat sehingga pada akhirnya negara menjadi kuat. Hal ini ditegaskan oleh Nabi bahwa:"seorang imam (khalifah) adalah pemelihara dan pengatur urusan (rakyat) dan dia akan diminta pertanggung jawabannya terhadap rakyatnya."

Ketika khalifah Umar membuat perencanaan melalui kebijakan ekonomi dengan mendirikan Baitul mal serta diwan-diwan yang mengatur sumber-sumber pemasukan/pendapatan harta dan pendistribusiannya baik dari sumber primer (pemasukan tetap) maupun sekunder (pemasukan tidak tetap) dengan azaz keutamaan. Kemudian 
mengalokasikan sebagai pengeluaran yang rutin maupun temporal. Dengan kata lain khalifah Umar menggunakan fungsi Baitul mal untuk mengelola keuangan negara menggunakan akumulasi dana yang berasal dari berbagai pemasukan dari sumber primer dan sumber sekunder.

Dengan demikian dapat dilihat bahwa Islam memiliki sebuah sistem kenegaraan yang menjunjung tinggi nilai-nilai kesejahteraan bagi warga negaranya serta mampu menghadirkan kesejahteraan bagi semua warga negaranya tanpa adanya diskriminasi terhadap non-muslim. Secara umum nilai-nilai Islam memiliki sebuah konsep negara kesejahteraan yang berlandaskan pada etika dan moralitas Islam. Perencanaa-perencanaan yang tertuang dalam pidatonya pada waktu diangkat menjadi khalifah menjadi tolak ukur kemampuan Umar dalam merencanakan distribusi ekonomi yang adil dalam situasi dan kondisi pemerintahan pada saat itu. Umar bahkan mampu mengaktualisasikan kebijakannya tersebut dengan diwan-diwan yang telah dibentuknya melalui persetujuan dewan syura'.

Pemasukan serta pengeluaran (distribusi) kepada orang-orang yang berhak ditetapkan dituliskan oleh pegawainya menjadi patokan pelaksanaan pemberi tujangan dan jaminan sosial. Dalam kebijakan strategi penggunaan pendapatan negara (pengeloaan dan pendistribusian) tergantung pada perkembangan atau kondisi perekonomian negara pada satu waktu tertentu. Artinya pengembangan institusi dan kebijakan ekonomi tidaklah terikat pada apa yang telah dilakukan oleh para pemimpin terdahulu. Peran ijtihad dengan memepertimbangkan keadaan kontemporer menjadi sangat menentukan arah dan bentuk institusi dan kebijakan ekonomi. Dalam sistem ekonomi Islam, kebijakan fiskal merupakan suatu kewajiban negara dan menjadi hak rakyat. Kebijakn fiskal dalam sistem ekonomi tidak bertumpu pada pertumbuhan ekonomi seperti dalam ekonomi konvensional tetapi mengacu pada penciptaan mekanisme distribusi ekonomi yang adil.

Khalifah Umar telah mempelopori penerapan independensi Baitul mal dalam pemerintahan Islam dari kekuasan ekskutif . Dengan keadaan inilah kemudian khalifah Umar berinisiatif menjadikan Baitul mal sebagai lembaga independent agar tidak bercampur baur dengan urusan administrsi lain. Sehingga Pemasukan dan pengeluaran harta Baitul mal dapat terkontrol. Umar memberikan ketegasan bahwa tidak ada intervensi penguasa dalam pembagian harta Baitul mal karena harta Baitul mal akan dibagikan berdasarkan haknya. Khalifah Umar menegaskan bahwa dia tidak mempunyai hak istimewa atas harta Baitul mal bahkan dalam menentukan berapa banyak gaji yang harus diperoleh khalifah (dirinya sendiri). Khalifah Umar mengumpulkan umat Islam untuk bermusyawarah dalam menentukan gajinya tersebut. 
Dengan demikian khalifah Umar telah mengunakan unsur manajemen walaupun secara teori pada saat itu belum tersistematisasi seperti teori manajemen sekarang (teori ala Barat), namun sudah menjadi keniscayaan bagi seorang pemimpin (khalifah) dalam pemerintahan untuk melakukan hal itu. Secara garis besar fungsi negara dalam mengelola sektor ekonomi publik terbagi atas tiga fungsi, yakni fungsi alokasi, fungsi distribusi, serta fungsi stabilitas. ${ }^{70}$ Dalam fungsi alokasi negara mengatur bagaimana seharusnya alokasi sumber daya ekonomi dapat dimanfaatkan secara adil dan efisien. Dalam fungsi distribusi negara harus memastikan bahwa seluruh anggota masyarakat dapat menikmati hasil-hasil dari pembangunan berupa tercukupinya kebutuhan hidup minimum.

Fungsi stabilitas dalam hal ini merupakan suatu kondisi sosial ekonomi. Terget dari stabilitas sosial ini adalah terciptanya interaksi sosial kemasyarakatan yang dinamis dan harmonis, hubungan antara umat Islam sendiri maupun dengan kaum dzimmi, keharmonisan ini terjaga karena masing-masing saling hidup berdampingan. Tujuan dari stabilitas dalam sebuah ekonomi adalah tercipta keadilan ekonomi yang dijalankan dengan sistem Islam sehingga pertumbuhan ekonomi dan kesempatan kerja penuh sebagai sarana untuk menciptakan distribusi ekonomi yang adil. Dengan demikian khalifah adalah penanggung jawab rakyat, sedangkan rakyat adalah sumber pemasukan kekayaan negara yang manfaatnya kembali kepada mereka dalam bentuk jasa dan fasilitas umum yang diberikan Negara.

\section{KESIMPULAN}

Periode kepemimpian Umar bin Khathab adalah masa keemasan bagi umat Islam dalam periode Khulafaur Rasyidin. Walaupun sebenarnya pada masa kepemimpinan politik Rasulullah dan Abu Bakar negara Madinah sudah menjadi sebuah model negara yang sejahtera Namun ketika itu Baitul mal belum permanen. Pada masa khalifah Umar lah negara Madinah mengalami penyempurnaan. Kesempurnaan pemerintahan pada masa khalifah Umar tidak hanya dilihat dari lahirnya institusi-institusi yang menopang dalam pemerintahannya, akan tetapi kesempurnaan itu dapat dilihat dari bagaimana cara Umar mencurahkan kekuasaan negara untuk kesejahteraan rakyatnya dengan pengemengelolaan harta Baitu mal.

Pada masa itu belum ada teori manajemen seperti pasa saat sekarang namun khalifah Umar sebagai seorang pemimpin mampu memberi motivasi serta memberikan nasehat dan mendorong amir dan pegawainya dengan mengedepankan nilai-nilai keislaman dan ketauhidan dalam melaksanakan tanggungjawabnya. Umar telah memberikan konstribusi

\footnotetext{
${ }^{70}$ Nurul Huda dkk, op,cit. h. 53
} 
besar dalam pemerintahan Islam pada masa Khulafaur Rasyidin dalam segi ketatanegaraan dari kebijakan-kebijakan praktis, teknis dan operasional untuk sebuah Negara yang undangundangnya didasarkan pada al-qur'an dan sunnah Rasulullah SAW.

\section{DAFTAR RUJUKAN}

Abbas Mahmud Al-Akad, Abaqariayu Umar, terj Gaziroh Abdi Ummah, Kejeniusan Umar, Jakarta: Pustaka Azam, 2002

Abdul Qaddim zallum, Sistem Keuangan Negara Khilafah, (Jakarta: HTI Pres, 2008).

Abu Ubaid al-Qasim, Kitab Al-Amwal, terjemahan Setiawan Budi Utomo, Jakarta:Gema Insani, 2006

Affandi, Adang , Studi Sejarah Islam, t.t : Bina Cipta, 1995

Afzalur Rahman, Doktrin Ekonomi Islam, judul asli "Economi doctrines of Islam Jilid 1, diterjemahkan oleh Soeroyo dan Nastangin, Yogyakarta: PT Dana Bhakti Wakaf, 1995

Afzalurrahman, Economic Doctrines of Islam terj. Soeroyo dan Nastangin, Doktrin Ekonomi Islam, 1, Yogyakarta: Darma Bakti Wakaf, 1995

Ahmad Ibrahim Abu Sinn, Manajemen Syariah judul asli Al-Idarah fil Islam, penerjemah Jakarta: PT Raja Grafindo, 2006

al-Qaradhawi, Yusuf, "Malamih al-Nujtama al-Muslim allazi Nansyuduh, kairo maktabah Wabah, 1993

an-Nabhani, Taqyudin, Membangun Sistem Ekonomi Alternatif Prespektif Islam. Judul asli AnNidhan al-Iqtisadi fil Islam, penerjemah Moh Maghfur Wachid cet ke 5, Surabaya: Risalah Gusti, 2000

Atho', Mustofa Abdul Qodir, Mustadarok ala Shohihain, juz 3 bab Ma'rifah Shohabah, Beirut: Dar al-Kutub al-Ilmiyah, t.t

bin Ahmad al-Haritsi, Jaribah, Fiqih Ekonomi Umar bin Khatab. Judul asli Al-Fiqih al-Iqtishadi li Amiril Mukminin Umar bin Khatab, terjemahan Asmuni Solihah Zamakhsyari, Jakarta: Pustaka al-Kautsar, 2014

Gusfahmi, Pajak Menurut Syariah. Jakarta: PT Raja Grafindo, Persada, 2008

Hidayat, Mohammad, The Sharia Economic Pengantar Ekonomi Syariah, Jakarta: Zikrul Hakim , 2010

Hidayat, Mohammad, The Sharia Economic Pengantar Ekonomi, Jakarta: Zikrul Hakim, 2010 
Husain Haekal, Muhammad, Umar bin Khatab, diterjemahkan oleh Ali Audah judul asli AlFaruq Umar, Bogor: Lintera AntarNusa, 2013

Irfan Raana, Mahmud, Sistem Ekonomi Pemerintahan Umar, Jakarta: Pustaka Firdaus,

Ismail bin Umar bin Katsir asy-Syafi'i (al-Hafiz Ibnu Katsir), Al-Khulafa' Ar-Raasyidun perjemah oleh Umar Mujtahid, Jakarta: Perisai Qur'an, 2012

Ismail bin Umar bin Katsir Asy-Syafi'i (al-Hafiz Ibnu Katsir), Serial Al-khulafa' Ar-Rasyidun 2 Umar bin Khaththab, Judul asli Al-Khulafa' Ar-Raasyidun penerjemah Umar Mujtahid, Jakarta: Perisai Qur'an, 2012

James A.F.Stoner, R.Edwar Freeman dan Daniel R. Gilbert JR., Management, New Jersey: Prentice-Hall, Inc.A. Simon \& Schuster Company, 1995, diterjemahkan oleh Alexander Sindoro, Managemen 1, Jakarta:PT Buana Populer, 1996

Kastin Hasan, Surtahman, Ekonomi Islam; Dasar dan Amalan (Dewan Bahasa dan Pustaka, 2001

Khalid, Amru, "Jejak Para Khalifah"terjemahan Farur Mu'is judul asli "Khulafaur Rasul", Solo:Aqwam, 2007

M Fuad, Christin H dkk, Manajemen Bisnis,(Jakarta: PT Gramedia, 2006),h. 92-93Jawahir Tanthowi, Unsur-Unsur Manajemen Menurut Ajaran al-Qur'an Jakarta: Pustaka al-Husna, 1983

Majid, Nazori, Pemikiran Ekonomi Abu Yusuf Relevansinya Dengan Ekonomi Kekinian,Yogyakarta: PSEI, 2003

Muhammad, Kebijakan Fiskal dan Moneter dalam Ekonomi Islam, Jakarta: Salemba Empat, 2002

Nazir, Moh, Metode Penelitian, cet ke 3, Jakarta: Ghalia Indonesia1988

Nurul Huda dkk, Keuanagan Publik Islam Pendekatan Teoritis dan Sejarah, Jakarta: Kencana Prenada Gurp, 2012

Prasetyo, Bambang, Lina Miftahul Jannah, Metode Penelitian Kualitatif Jakarta: Raja Grafindo Persada, 2005

Qadhi Abu Yusuf Ya'qub ibn Ibrahim, Kitab al-kharaj, (Beirut: Dar al-Ma'rifah, 1989

Rozalinda, Manajemen Waqaf Produktif, Jakarta:RajaGrafindo Persada, 2015

Sami bin Abdullah al-Maghlout, Jejak Khulafa Rasyidin 2 Umar bin Khatab, judul asli Atlas alKhaliafh Umar bin al-Khatab, diterjemah oleh Muflih Kamil, Jakarta: Almahira, 2014

Sinn, Ahmad Ibrahim Abu, Manajemen Syariah: Sebuah Kajian Historis dan Kontemporer, judul asli Al-Idarah fi Al-Islam terjemahan Dimyauddin Djuwaini, Jakarta: PT Raja Grafindo, 2008 
Syalabi,A, Sejarah dan Kebudayaan Islam Jilid 1, Jakarta: PT Al-Husna Zikra, 1997

Syamsudin, M.Din, Esiklopedi Tematis Dunia Islam, Vol II Jakarta: PT Ichtiar Baru Van Hoeve, 2002

Taufiqurohman, Sejarah Sisosial Politik Masyarakat Islam, Surabaya: Pustaka Islamika Press, 2003

Winarno, Sigit, Kamus Besar Ekonomi, Bandung; Pustaka Grafika, 2010

Wiryaputra, Sugianto, Dasar-Dasar Manajemen, Jakarta: BPK Gunung Mulia, 2008

Zallum, Abdul Qadim, Sistem Keuangan Negara Khalifah terjemahan Ahmad S, judul asli AlAmwal Fi Daulah Al-Khilafah, Jakarta: HTI Press, 2008. 